Portland State University

PDXScholar

1987

\title{
The politics of disestablishment : Gladstone and the Fenians
}

Robert Emmett Lanxon

Portland State University

Follow this and additional works at: https://pdxscholar.library.pdx.edu/open_access_etds

Part of the European History Commons, and the Political History Commons Let us know how access to this document benefits you.

\section{Recommended Citation}

Lanxon, Robert Emmett, "The politics of disestablishment : Gladstone and the Fenians" (1987).

Dissertations and Theses. Paper 3717.

https://doi.org/10.15760/etd.5601

This Thesis is brought to you for free and open access. It has been accepted for inclusion in Dissertations and Theses by an authorized administrator of PDXScholar. Please contact us if we can make this document more accessible: pdxscholar@pdx.edu. 
AN ABSTRACT OF THE THESIS OF Robert Emmett Lanxon for the Master of Arts in History presented July 16, 1987.

Title: The Politics of Disestablishment: Gladstone and the Fenians.

APPROVED BY MEMBERS OF THE THESIS COMMITTEE:
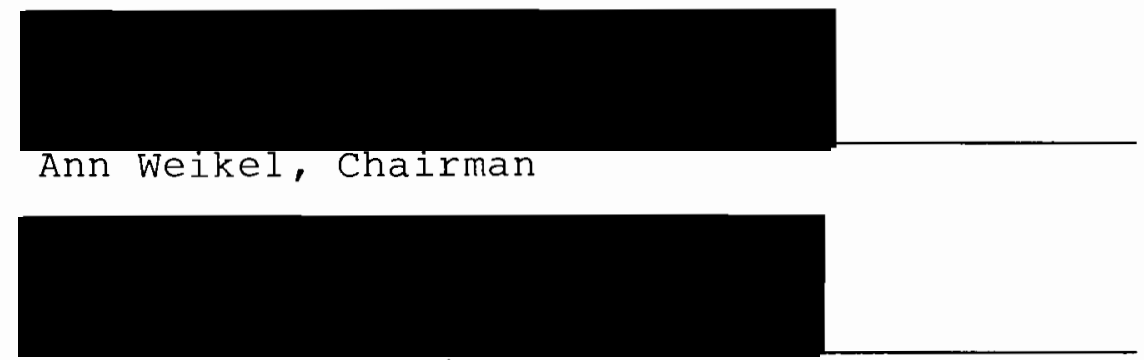

Charles A. Le Guin

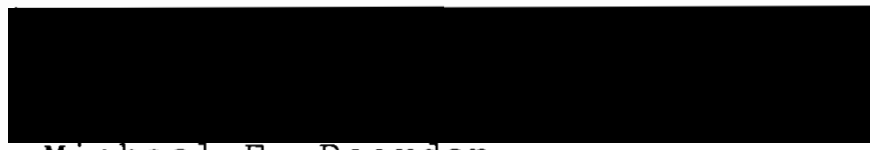

Michael F. Reardon

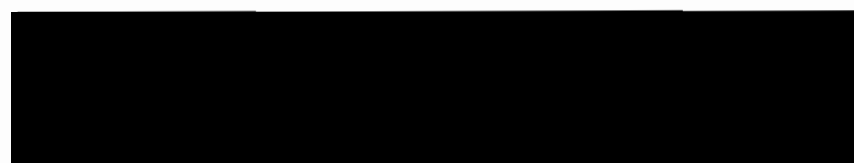

Shelley CO Reece

In early 1868 William E. Gladstone presented several

bills in Parliament to disestablish the church of Ireland. Prior to $1868 \mathrm{Gladstone}$ had stated his opposition to the official connection between the Church of Ireland and the State. Gladstone, however, had also claimed that he was not in favor of immediate action and instead advocated restraint in attacking the Church of Ireland. The 1860's also saw the rise of the Fenian organization. The Fenians were dedicated to the overthrow of English rule in Ireland and the 
establishment of an Irish republic. The role that the Fenians played in convincing Gladstone to disestablish the Irish church has received varying interpretations from historians; yet no attempt has been made to look closely at the issue.

The most important source available is Hansards Parliamentary Debates. Much of the formal discussion on the issue of church disestablishment took place in the House of Commons. Hansards gives an excellent account of the arguments pro and con on this issue. Hansards also provides the best available evidence of Gladstone's changing attitude toward the necessity of action on the question of church disestablishment. Various diaries, newspapers, periodicals, and at least one book written during the period in question (J. F. Maguire's The Irish in America) were used to assess the reactions of Gladstone's contemporaries. These sources were also used to determine the state of English opinion toward the Irish in general, the Fenians in particular, and English views on the necessity of Irish reform.

The execution of three Fenians in 1867 prompted an outpouring of sympathy for these "martyrs" from the Irish-including some Irishment who had previously been unsympathetic toward the Fenian movement. Gladstone had hoped to proceed in a calm and deliberate manner on the question of disestablishment. He realized, however, that reform of the Irish church could not be delayed any longer. Gladstone 
feared that further delay would increase popular sympathy for the Fenians in Ireland, which he also feared would encourage many of the Irish to question the wisdom of the Union between England and Ireland. He hoped that prompt redress of Irish grievances, of which disestablishment was one of the most prominent, would encourage the Irish to maintain the Union. 


\title{
THE POLITICS OF DISESTABLISHMENT:
}

\section{GLADSTONE AND THE FENIANS}

by

\author{
Robert Emmett Lanxon
}

A thesis submitted in partial fulfillment of the requirements for the degree of

\author{
MASTER OF ARTS \\ in \\ HISTORY
}

Portland State University 
TO THE OFFICE OF GRADUATE STUDIES AND RESEARCH:

The members of the committee approve the dissertation of Robert Emmett Lanxon presented July 16, 1987.

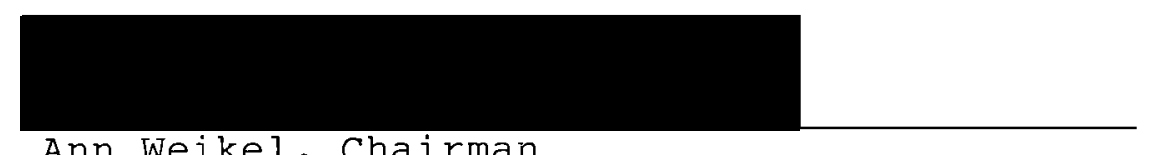

\section{Ann Weikel, Chairman}

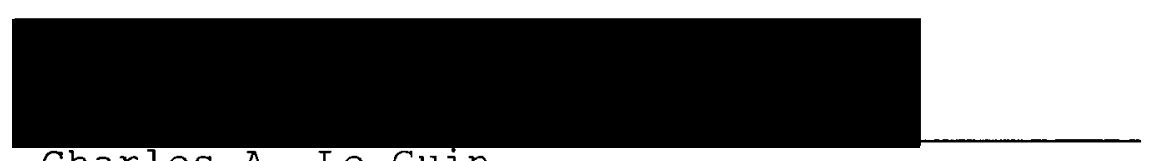

Charles A. Le Guin

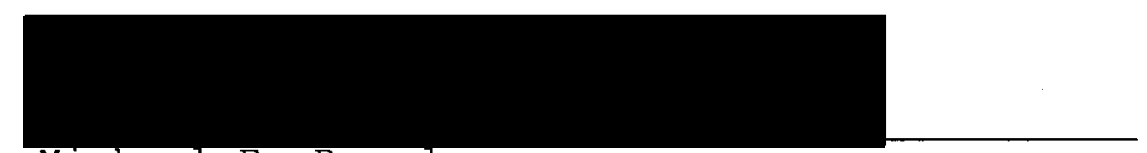

Michael F. Reardon

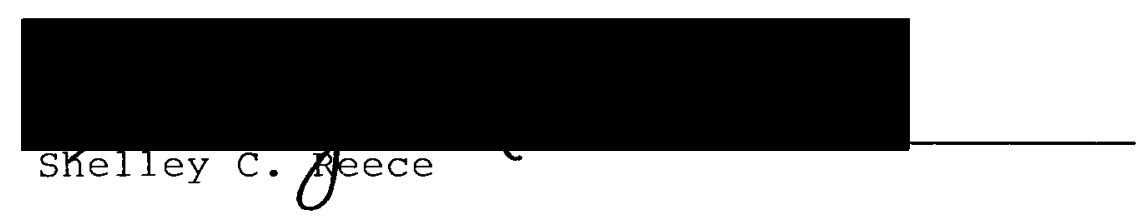

APPROVED :

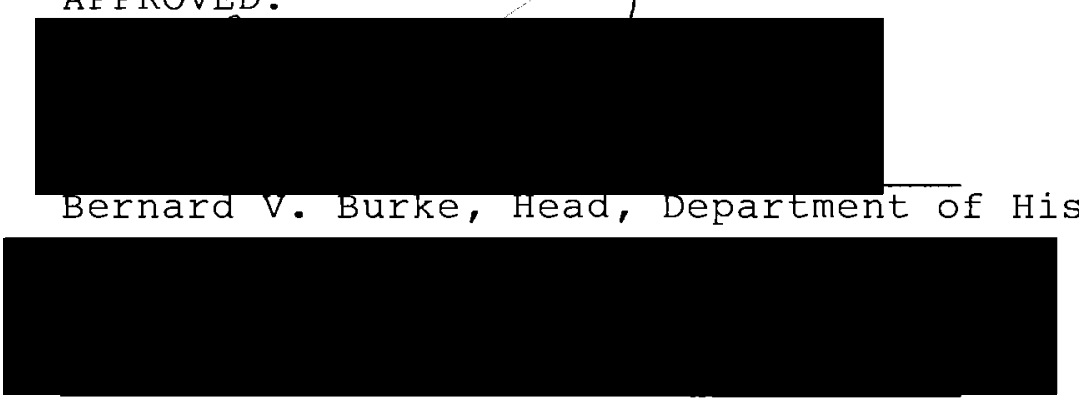

Bernard Ross, Dean, Graduate Studies and Research 
TABLE OF CONTENTS

PAGE

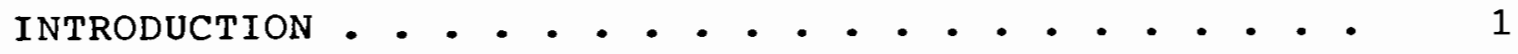

Notes . . . • . . . • . . . . . 15

CHAPTER

I DISESTABLISHMENT PROPOSAL • • • • • • • • . . 18

Introduction . . - . . . . - . . . . 18

Parliamentary Action and the Church of

England . . . . . . . . . . . . 20

Dillwyn's Motion, 1863

Dillwyn's Second Motion, 1865

Gray's Motion, 1866

Gray's Second Motion, 1867

Notes • • • • • • • • • • • • • • • •

I I THE UNSYMPATHETIC REACTION: THE

CONSERVATIVES . . . . . . . . . . . . . . 48

Dillwyn's First Motion - 1863 . . . . . 50

Dillwyn's Second Motion - 1865 . . . . . 52

Gray's First Motion - 1866 . . . . . . 54

Gray's Second Motion - 1867 . . . . . . 56

Notes . . . - . . . . . . . . 58

III "THE TIME IS NOT RIGHT": GLADSTONE'S

REACTION TO EARLY DISESTABLISHMENT MOTIONS

IN PARLIAMENT . . . . . . . . . . . . . 61

Dillwyn's First Motion - 1863 . . . . . . 62

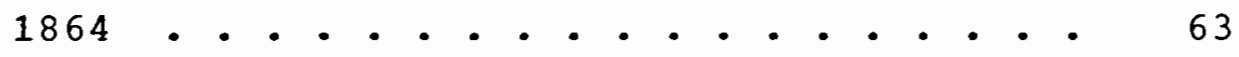

Dillwyn's Second Motion - 1865 . . . . 64 
Gray's Motions, 1866 and 1867 . . . . . 66 $1867-1868$. . . . . . . . . . . 79

Notes . . . . . . . . . . . . 81

IV THE FENIANS - . . . . . . . . . . . . . 84

The Catholic Church and the Fenians . . . 87

The English and the Irish Catholic Church . 90

The English and the Fenians . . . . . . . 92

The Fenians, the United States and the

English, 1865-66 . . . . . . . . . 94

Suspension of Habeas Corpus . • . • • . 98

1867 - Chester Castle, Manchester, and

Clerkenwell............ . 102

Notes . . . . . . . . . . . . 110

V GLADSTONE, THE FENIANS AND CHURCH

DISESTABLISHMENT • • • • • • • • • • • • 115

Notes • . • • • • . • • • . • • 129

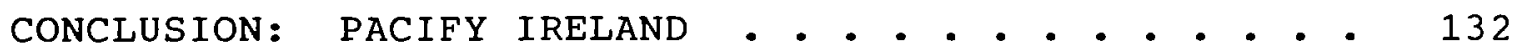

Notes . . . . . . . . . . . . 135

SELECTED BIBLIOGRAPHY • • • • • • • • • • • • • 136

Primary Material • . . . . • . . . 136

Secondary Material . . . . . . . . 138 


\section{INTRODUCTION}

In late 1867, W. E. Gladstone, one of the leaders of the Liberal Party, reluctantly came to the conclusion that the Church of Ireland would have to be disestablished. Gladstone's motion in 1868 caused the downfall of the minority government of Disraeli. The elections in late 1868 were fought primarily on the issue of the disestablishment of the Church of Ireland. The Liberal victory in 1868 meant the end of the Church of Ireland as the officially established state church. ${ }^{1}$ In early 1869 legislation was introduced that not only disestablished the Church of Ireland, but also disendowed it. Despite disharmonious rumblings from the House of Lords, the bill became law, and on the 1st of January 1871, the Church of Ireland ceased to exist.

This thesis will argue that Gladstone was motivated, in large part, to disestablish the Irish church in 1869 by the potential threat of extensive Irish sympathy for the Fenian cause. Gladstone had refused to support the motions of 1863,1865 , and 1866 that had, in one fashion or another, attacked the established church in Ireland. In 1867 he was willing to give his personal support, but not the support of the Liberal Party, to the issue of disestablishment. Gladstone's gradual acceptance of the necessity of action on 
the question of the Irish church was motivated by the increasing popularity of the Fenians in Ireland. In the $1860 \mathrm{~s}$, Gladstone had taken part in all of the debates on the Irish church, except in 1866, when he did not enter the debate on Gray's motion ${ }^{2}$ and expressed his opinion that the Irish church was an injustice that would have to be taken care of sometime in the unforeseeable future. Gladstone was a cautious politican--he felt that precipitate change was to be as feared as injustice. Thus he preferred to address the question of the Irish in a slow and deliberate manner. Discontent in Ireland, and the Fenians in particular, gradually convinced Gladstone that immediate action was necessary. Once Gladstone realized that further delay might create even more public sympathy for the Fenians and further threaten the union between Ireland and England, he moved quickly to remove the sources of Irish discontent, one of which was the Church of Ireland as a state-supported institution. ${ }^{3}$ Gladstone hoped that disestablishment would make the Irish more amenable to English rule.

The debate on disestablishment took place against a backdrop of rising discontent in Ireland, of which discontent the Fenians were the most conspicuous example. ${ }^{4}$ The Fenians came to the notice of the English authorities in 1863, at which time they were considered to be inconsequential. By 1865 the organization had grown so rapidly that the English quickly moved in, arrested the 
leaders, and closed down their newspaper, The Irish People. The English became so worried about the spread of the organization that in 1866 the Liberal government under the leadership of Russell asked for, and got, a suspension of the Act of Habeas Corpus in Ireland. Throughout 1866 the Fenians remained relatively quiet. In 1867 they illustrated their determination to establish an Irish republic: they attempted a raid on the munitions depot at Chester castle and engaged in a series of abortive risings in Ireland. 5 In late 1867, three Fenian conspirators were executed at Manchester for their part in the death of an English policeman. ${ }^{6}$ In December 1867 , the Fenians blew a hole in the wall of clerkenwell prison in an attempt to rescue some of their brethren. They used too much dynamite and several people in the surrounding neighborhood were killed. The execution of the "Manchester Martyrs" generated a substantial amount of sympathy for the Fenians in Ireland. The Clerkenwell explosion enraged English opinion.

Assessing Gladstone's motives for many of his actions can be difficult, for Gladstone was a complicated man. He had not always been a liberal: he had first sat in Parliament as a Canningite Tory, and in 1831 and 1832 he had actively opposed parliamentary reform (which he voted against in Parliament). The battle for the repeal of the Corn Laws in 1846 had transformed his political position; Gladstone found himself between the two major parties as a 
Peelite. Finally, in 1859, he decided to join the Liberal government of Lords Palmerston and Russell.

Theologically, Gladstone started out as an evangelical (under the influence of his sister) and was very conservative in his views on the correct relationship between church and state. In 1838 he published a book entitled The State in Its Relations With the Church. His book defended the current relationship between the Churches of England and Ireland and the state. Gladstone basically argued that the state had a conscience and was obligated to support true and correct religion, i.e. Anglican, wherever it could. By 1845 his religious views had changed; he had become a high Anglican under the influence of the oxford Movement. He also no longer believed that the state was able to determine truth in religion. On the other hand, Gladstone never stopped hoping that "there would be one Church and that the main role of the state would be to support it. . ." Until his death in 1898, he was willing to come out of retirement to defend the Church of England against the disestablishment schemes of the dissenters and radicals. Gladstone recognized, however, that he lived in an imperfect world, and that his goal could not be achieved. Thus it was necessary, according to Gladstone, for the state to be as neutral toward other religions as possible. 8 This transformation of Gladstone's beliefs and political alliances caused many problems in assessing 
Gladstone's role in the politics of disestablishment. Were his motives political, religious, or some combination of the two? While I have chosen to focus on the political rather than on the religious aspects of Gladstone's realization in late 1867 that the Irish church had to be disestablished immediately, Gladstone's views on religion are not to be disregarded.

Religion was an important and significant aspect of Gladstone's whole life. One historian had gone as far as to state that his "primary interests were religious, not political." 9 This assessment is, in many ways, too extreme. Gladstone had a deep interest in both religion and politics. In 1832 he had struggled with the question of whether he should go into the church or if he should remain in politics; he chose to remain in politics. The historian may be able to separate politics from religion, but in Gladstone's mind they were too interwoven to be pulled apart so easily. When Gladstone had finally decided upon the necessity of championing Irish reform, it is not surprising that he first acted on a religious issue. Still, this thesis will contend that the political issue of Irish reform and its connection with the Fenians was the most important issue to Gladstone in 1867 and 1868. Whatever his feelings were toward state-supported religions in the early 1860s, they were not enough to prompt him to action on the question of disestablishment. It took the threat of widespread Irish 
sympathy for the Fenians to convince Gladstone that there was no time to be wasted in addressing the issue of the Irish church.

The question is, why did Gladstone wait until 1868 to present motions that would disestablish and disendow the Church of Ireland, when he had had several chances to do so before then? Many interpretations exist, but none are entirely complete or correct.

E. J. Feuchtwanger focuses on Gladstone's sense of justice and fair play. Feuchtwanger sees Gladstone's disestablishment bill as an act of atonement for past wrongs done to Ireland. ${ }^{10}$ Peter Stansky has focused on Gladstone's changing religious beliefs. Stansky feels that Gladstone's actions were intended to strengthen the Church of Ireland:
- . in Ireland the establishment was very much a minority church, financially supported under duress by a people of a different and antagonistic faith. In such a situation, Gladstone believed that the Church of Ireland would be helping itself to find strength and new life through disestablishment.

Although Stansky focuses on a different theme than Feuchtwanger, Stansky essentially agrees with Feuchtwanger when he states that Gladstone's appeal "rested on the use of politics for moral ends."12

These books, by their omission of the Fenians, have implied that the Fenians played an insignificant role. J. C. Beckett is more direct in his negative assessment of the role of the Fenians in Gladstone's decision to promote 
disestablishment in 1868 :

It is an error to suppose that it was Fenianism that disposed the British public to accept the remedial measures that he was shortly to put forward.

While other historians have discussed the influence of the Fenians, they do not give them much credit in their discussions. Gladstone's two most well known biographers, John Morley and Philip Magnus, indicate that the Fenians played some role in convincing Gladstone that the time for action was near. Morley leaves the reader with the impression that Gladstone was waiting for public opinion to ripen on the question of disestablishment. Gladstone's ability to feel the pulse and tempo of British public opinion was proven correct "by the result."14 Magnus, for his part, comments that "two bomb outrages perpetrated in England by Irish Fenian conspirators in September and December, 1867, had impressed Gladstone without unduly influencing him."15 Neither Magnus nor Morley give the Fenians enough credit for their role in the debate on the urgency of disestablishment.

Histories of both England and Ireland contain passages that briefly note the importance of the Fenians. Donald Read in his history of England states". . Gladstone regarded the Fenian outrages not as a reason for pursuing a course of negation in Ireland, but for promoting a policy which would seek to remove the grievances exploited by the Fenians." 16 Patrick O'Farrell notes that the violence of 
the Fenians "prompted the English government to make reforms which moderates had proposed earlier as essential in order to avoid violence." 17

E. L. Woodward is more cautious, and more contradictory, in his approach toward the issue of the influence of the Fenians. Woodward states that "Gladstone's mind was made up even before Fenianism shewed the danger of delay; in 1868 he told Granville that, for years past, he had been watching the sky with a strong sense of obligation to act with the first streak of dawn."18 Yet, later in his book, he seems to emphasize the importance of the Fenians:

Ireland was still unreconciled to English rule, but the failure of the leaders to obtain anything like the support which O'Connell had secured a generation earlier showed that, perhaps, Ireland was not irreconcilable. The redress of agrarian grievances, and the abolition of the privileges of the Anglican Church, might even yet bring about this long-delayed reconciliation. Such was the reasoning which persuaded Gladstone to take up the questions of Irish land tenure and the Irish church. The Fenian movement helped to convince him that delay was dangerous.

There are dangers involved in focusing on the Fenians and disestablishment. The first is that a study such as this tends to focus attention on a very narrow subject to the exclusion of other topics. Church disestablishment became only a part of a package of general reform that ultimately also included acts on land and education. The other problem is a danger that is pointed out by E. R. Norman:

But too great an emphasis on the revolutionaries of this decade has led many historians into a 
disproportionate neglect of the other political movements which then ran their course. In fact, the most substantial political feature of the 1860 's was not the Fenians, but the emergence of a coherent Liberal party in Ireland 2 ynder the direct patronage of the Catholic Church.

While Norman may be correct in emphasizing other groups and organizations that were more important to long term Irish politics, this thesis attempts to understand the short term importance of the Fenians on Gladstone's decision to disestablish the Irish church.

The issue of Fenianism, church disestablishment, Gladstone, and the connection between the three is clouded and unsure. That fact on its own speaks eloquently for the need of an in depth study. ${ }^{21}$ Most of the sources already cited briefly address the issue of Gladstone and the Fenians. All the authors have their individual views of what the influence of one was upon the other. They do not, however, go into great detail. A study such as this would go a long way toward ending some of the confusion and contradiction.

The possible benefits of this study are numerous. The most obvious is the light it may throw on Gladstone's political nature. It will not produce any startling revelations about Gladstone's personality and politics. A limited study of one event in 1868-1869 cannot seriously challenge the detailed synthesis of the years of material that make up a biography. It can, however, support themes that have been emphasized in other works. The Fenians had 
an important role in convincing Gladstone to act upon the issue of disestablishment. This study confirms that Gladstone was capable of sudden, "volcanic" decisions to act upon his newly found convictions. As Philip Magnus maintains:

Gladstone's iron self-mastery, which held his volcanic energy in check, was operated by his intelligence and by his will. He never gave himself to any subject, whatever attractions it held for him, until he had first convinced himself that the time was ripe for bringing it forward. He believed that his instinct for 'right-timing', which his enemies called opportunism and greed for office, was his outstanding gift as a statesman. And the seismic way in which that instinct sometimes appeared to operate, was 22 measure alike of the vehemence of his nature.

If the Fenians did force the English to consider Irish reforms, what, in part, would be the benefits of such reforms? Again, this question touches on Gladstone's concept of religion. Although he had come to the conclusion that the state did not necessarily have an obligation to determine religious truth, religion none the less played an important role in politics. Without a strong moral base on which society stabilizes, he thought society, political and civil, could disintegrate into anarchy. The Protestant church in Ireland had failed to find a following among the majority of the Irish. The Catholic church in Ireland had no real stake in insuring the stability of Irish society as long as there remained an officially established and sanctioned Church of Ireland. The Church of Ireland became 
an albatross around the neck of the civil authorities in Ireland. The Catholic church in Ireland would provide a stable and moral base for the continuance of English government in Ireland only after the destruction of the Church of Ireland had been accomplished.

What does this have to do with the Fenians? The Fenians themselves were not concerned with the religious question. The Fenians were primarily concerned with the establishment of an independent Irish republic. Why would Fenian violence influence Gladstone to attack the Church of Ireland? How could disestablishment, once enacted, affect the Fenians? Many Englishment, Gladstone included, felt that sympathy for the Fenians in Ireland was possible only because of outstanding grievances. English concern over the Fenian movement waxed and waned. At one moment the English were confident that repressive acts (such as the suspension of habeas corpus) could do the trick; while the next moment they became morbidly insecure and despondent when Fenian violence threatened to erupt, or when violence actually did erupt. Throughout the $1860 \mathrm{~s}$ the English found themselves confident that the Fenian movement would disappear when their various projects failed (such as the attempted invasions of Canada). At other times in the $1860 \mathrm{~s}$ the English found themselves outraged and puzzled by the continued violence of the Fenians--especially when that violence found its way onto English soil, as with the 
incidents at Manchester and Clerkenwell.

Of greater significance to English statesmen, was the effect that the Fenians had on the Irish. Most of the Irish were not active Fenians. The Fenians, however, fed off of the considerable sympathy the Irish were willing to give any movement willing to oppose the English. ${ }^{23}$ The Catholic church, officially, was against all secret societies, including the Fenians. The Catholics, however, did not speak with one voice. Bishop McHale, Father Lavelle, and a large number of parish priests found it more desirable to either remain neutral or to show outright support for the Fenians. More significantly, the feeling of discontent illustrated by the Fenians helped the Irish to focus their attention on issues tangential to the Fenian movement. 24 As one proponent of the Irish reform put it:

Though an organization may be ill-designed or even ridiculous, or, on account of the folly, or violence, or treachery, of those who are responsible for its management, may come to a speedy dissolution, if it have its origins in an earnest and enduring feeling, it is significant of danger--it represents more than is seen; and die down as it may, it $2 \frac{j}{5}$ sure to spring up again in some new form.

Disestablishment could mollify Ireland so that future groups such as the Fenians could not find fertile ground on which to grow.

There are several other issues connected with the Fenian movement that this paper cannot, in more than a cursory manner, address. One is the ultimate consequence 
of the reality, or appearance, of English reform occurring only after the Irish had turned to violence. ${ }^{26}$ This paper will analyze whether or not Fenian violence was responsible, in large part, for convincing the English of the need for reform. This paper cannot, due to its limited scope, come to a satisfactory conclusion as to whether or not this canonised violence was the only means of bringing the English to the bargaining table. An answer to that question depends more upon Irish perceptions of what prompted the English to support reform than it does on the reality of what got the English to finally address Irish grievances.

This paper attempts to provide some insights into the nature of British political reform, especially reform that affected Ireland. It is important to assess the influence of the Fenians on Gladstone. Gladstone, after 1868, became the champion of Irish reform, eventually embracing Home Rule in the 1880s. Gladstone, as the leader of the Liberal Party for much of the nineteenth century, was responsible for interpreting, and enacting, the desires of the English, the Irish, and, finally, the members of the Liberal Party. In what manner Gladstone approached the question of reform and under what conditions he felt it necessary to enact proposals for reform are important.

The question is not, why did Gladstone believe in disestablishment? That is a separate topic. The question 
is, why did he come to the conclusion in late 1867 that the time for disestablishment of the Irish church was at hand? How did the Fenian movement influence that decision? The evidence supports the contention that the Fenians played a significant role in Gladstone's decision to pursue the question of disestablishment. One intent of the disestablishment bill was to undercut potential popular support for the Fenians by granting reform that would satisfy the majority of the Irish, and defuse the Catholic clergy's rancorous invective and hatred of English governance. Gladstone hoped that once disestablishment had been enacted, along with reforms of land tenure and education, the Irish would be reconciled to English rule. Once the Irish were reconciled to English rule, movements like the Fenians would cease to pose any danger to the security and well being of the union between England and Ireland. 
Notes

1 The Liberals were returned with a majority of 112. 2 see pages 66-68.

3 The other two issues to be addressed were the questions of land tenure and state-supported education.

4 The Irish Fenians formed an organization in 1858 called the I.R.B. (the Irish Revolutionary, or Republican, Brotherhood). The Fenians were formed in 1859 in the United States. The British referred to both organizations as "Fenians." This paper will follow that practice, i.e. the term Fenians will refer to the Irish organization. The Fenians in the United States will be designated as such.

5 see page 102 .

6 See pages 102-104.

7 Peter Stansky. Gladstone. A Progress in Politics (New York: W. W. Norton, 1979) 42.

8 stansky $42-43$.

9 J. L. Hammond and M. R. D. Foot, Gladstone and Liberalism (London: English UP, 1966) 2 .

10 see E. J. Feuchtwanger, Democracy and Empire. Britain 1865-1914 (London: Edward Arnold, 1985). See also his biography, Gladstone (New York: St. Martin's Press, $1975)$.

11 Stansky 114.
12 Stansky 119. 
13 J. C. Beckett, The Making of Modern Ireland, 1603-1923 (New York: Knopf, 1966, 1969) 162.

14 John Morley, The Life of William Ewart Gladstone

(1903; New York: MacMillan Co., 1921) 250.

15 Philip Magnus, Gladstone: A Biography (New York:

E. P. Dutton, 1964) 196 .

16 Donald Read, England, 1868-1914: The Age of Urban

Democracy (New York: Longman, 1979) 175.

17 Patrick O'Farrell, Ireland's English Question

(New York: Schocken Books, 1971) 97.

18 Ernest L. Woodward, The Age of Reform (1938;

Oxford: Clarendon Press, 1962) 182.

19 Woodward 346 .

20 E. R. Norman, A History of Modern Ireland (London:

Allen \& Unwin, 1971) 170.

21 E. R. Norman, The Catholic Church and Ireland in

the Age of Rebellion (Ithaca: Cornell UP, 1965).

22 Magnus 76.

23 In this case I am talking about the Catholic Irish, not the Protestant Irish. The majority of the Protestants in Ireland were Anglicans, and were quite happy with the religious settlement as it existed in Ireland.

24 A good example is the National Association, created in response to the Fenians, but in which its members concerned themselves primarily with the questions of church, land, and education. See Norman, The Catholic Church, 
25 John F. Maguire, The Irish in America (1867; New York: Arno Press, 1969).

26 This is the view of Patrick O'Connell, page 97. 


\section{CHAPTER I \\ DISESTABLISHMENT PROPOSAL}

\section{Introduction}

When Gladstone talked of "moving upon great questions of policy for Ireland" in $1869^{1}$ he had in mind the questions of disestablishment, land reform, and education. These issues were not new. All of them had been enunciated as a concern sometime before 1868 .

The question of the correct relationship between the state and the Church of Ireland had been argued at least since 1839, when Lord John Russell steered a motion through Parliament that set up a committee to inquire into a system for better distribution of Church of Ireland funds. Russell hoped to take some of the money from the Church of Ireland and expend it on "secular" projects in Ireland.

Gladstone had written his first book in 1837 on his conception of the true and correct relationship between the church and state. At that time he had defended the established church in Ireland. He claimed that the Church of Ireland was professing true religion, and in so doing it deserved the support and protection of the state. Gladstone's views changed quickly, however. As early as $1845 \mathrm{Gladstone}$ had stated that he could not consider himself 
loyal to the Church of Ireland as an established church any longer. Nor was this attitude unique to either the Conservatives or the Liberals. ${ }^{2}$ Benjamin Disraeli claimed in 1844 that the Church of Ireland was "an alien church." 3 The critical question is not, when did Gladstone change his attitudes toward the established church in Ireland? The critical question is, why did Gladstone wait until 1868 to act upon his convictions? Why had his attitude toward the necessity of disestablishing the Irish church changed in late 1867?

Despite condemnation of the Irish church by influential members of both parties, little or nothing was done. The potential problems associated with delay of long overdue reform was expressed in a warning in 1844 by the Member of Parliament for Buckinghamshire, Benjamin Disraeli. Disraeli described Ireland as a "dense population in extreme distress" who "inhabited an island where there was an Established Church which was not their Church," and who had "a territorial aristocracy, the richest of whom lived in distant capitals." Disraeli summed up the problems of the Irish: "they have a starving population, an absentee aristocracy, and an alien Church, and, in addition, the weakest Executive in the world." Disraeli finished his speech by posing a question, and answering it himself:

Well, then, what would hon. Gentlemen say if they were reading of a country in that position? They would say at once, the remedy is revolution. But the Irish [can] not have a revolution; and why? 
Because Ireland [is] connected with another and more powerful country. Then what [is] the consequence? The connection with England thus became the cause of the present state of Ireland. If the connection with England prevented a revolution, and a revolution were the only remedy, England logically [is] in the odious position of being the cause of all the misery in Ireland.

Although Disraeli's warning was not heeded, and no action was taken on any of the problems that he had described, his question and analyses were resurrected 19 years later when the question of the position of the church of Ireland was reopened by the member for Swansea, Lewis Dillwyn.

\section{Parliamentary Action And The Church of Ireland}

After years of sporadic efforts and talk, Parliament in the $1860 \mathrm{~s}$ became the battleground where the issue of disestablishment was fought. How the issue came to be introduced, and its transformation from a request for a select committee to look into the question of Temporalities to a call for disestablishment, are critical to an understanding of the influences on Gladstone. Gladstone was Chancellor of the Exchequer in 1863, and was present during many of the debates. Indeed, he was involved in several of the debates, as we shall see. We need to turn to those debates: first, to see what the issues were, and, second, to see if and how they influenced Gladstone. Then it will be possible to evaluate the influence of the Fenians . 
Dillwyn's Motion, 1863. Dillwyn's motion was, in comparison to later motions dealing with the Church of Ireland, timid and restrained. Dillwyn moved for a select committee to "inquire how far the present distribution of endowments for religious purposes throughout Ireland may be so amended as most to conduce to the welfare of all classes of Her Majesty's Irish Subjects." ${ }^{5}$ Dillwyn explained that the reason he was bringing up the question in Parliament was due to its difficulty; he felt that only governmental action could secure the necessary reform. ${ }^{6}$

Dillwyn's speech, however, questioned more than the use of church endowments. Dillwyn claimed that the Church of Ireland could only be maintained for two reasons: success of its mission in Ireland, or because of political necessity. Dillwyn felt that neither of these goals had been achieved.

Dillwyn felt that the Church of Ireland was a source of English weakness. He claimed that it alienated the Irish members of Parliament, that it was an international embarrassment, and that it was a drain on the resources of England. ${ }^{8}$ Furthermore, Dillwyn claimed, the Church of Ireland had failed as a missionary church. Dillwyn stated that in the province of Dublin, for instance, there had been 295,845 members of the Church of Ireland in 1844; in 1861 that number had dropped to $236,519 .{ }^{9}$ The Church of Ireland, according to Dillwyn, had no claim on the loyalty 
of either the Irish or Parliament based solely on the merits of its success as either a church or as an instrument of the state.

Dillwyn also doubted that the Church of Ireland could be maintained because of political necessity. Dillwyn felt that questions about the position of the Irish church were long overdue because of recent turbulence within Ireland-turbulence that was mainly attributable to the existence of the Church of Ireland. ${ }^{10}$ Discontent in Ireland could be overcome only if the English government would act quickly:

In England ministers of religion of all denominations [are] the best allies of the Government in the preservation of order, and they [are] prominent in every movement for the promotion of education and prosperity of the people. But that [is] not the case in Ireland, because the Catholic priest [feels] himself aggrieved by the maintenance of the Church Establishment, and [can] not be expected to be an ally of the Government in the preservation of order.

Since Dillwyn's ultimate objectives went beyond the question of the use of religious endowments, why did he limit his motion to only that question? For one, Dillwyn realized that any motion that dealt with the official establishment of the Church of Ireland questioned the Act of Union that had created it. As Dillwyn noted, the Act of Union required that the Churches of England and Ireland be united. Dillwyn also noted, however, that the Act of Union did not prevent questioning of the use of endowments. 12 Dillwyn's motion was a warning shot, a shot that was quickly turned into a protracted seige. 
The other reason for Dillwyn's timidity was his awareness that he was receiving little support from Irish Catholics or from the Irish M.P.'s. The Irish Catholics, for their part, were not yet organized. 13 only after the National Association had been formed did Catholics in Ireland take up the cry of disestablishment in earnest. 14 The Irish M.P.'s may have felt that they could not discuss matters pertaining to the Irish church because of the oath they had taken to preserve and support the Union. 15

Dillwyn had to proceed cautiously. For one, his question touched upon the fundamental basis for the official relationship between England and Ireland: the Act of Union. Secondly, Dillwyn was unsure of his support, despite his claim that the Irish were unhappy with their present condition. 16

Dillwyn's first motion is important for two reasons. First, because it put the issue before the House for the first time since 1859,17 thereby forcing Parliament to think about an issue that had seemed dormant for a long time. With the advantage of hindsight, we now know that this was the first of several measures spanning the 1860 s that eventually led up to the successful bill in 1869 that disestablished and partially disendowed the Irish church. Second, it is important because it introduced one of the critical arguments in favor of disestablishment: that unless there was a solid commitment for Irish reform, the 
Irish could not be counted on to remain loyal to the union between England and Ireland. His statement that England needed a loyal Catholic clergy to help maintain order touched a responsive chord four years later in many Englishmen who were puzzled and perplexed by the phenomenon (as they saw it) of Fenianism.

The debate on Dillwyn's motion was held May 19 th and was indefinitely adjourned until Parliament was officially ended in July of that same year without any action being taken. Eighteen sixty-four proved to be a quiet year for Parliamentary action regarding the church of Ireland. Parliamentary debate, however, was not quiet for long. Early in 1865 the issue was again brought before Parliament, again by Dillwyn.

Dillwyn's Second Motion, 1865. On March 28, 1865, Dillwyn introduced a new measure which stated that "in the opinion of this House, the present position of the Irish Church Establishment is unsatisfactory, and (this house) calls for the early attention of Her Majesty's Government." 18 This measure was much more strongly worded than the first.

The issues that were brought out in the debate on Dillwyn's second motion closely paralleled the issues debated during the first motion. Dillwyn started the debate by stating that the revenues of the Irish church were 586,428 pounds per year, all of which went to a church 
that ministered to 600,000 Anglicans. The majority of the Catholics, all 4.5 million, got nothing except for one tiny grant to the University of Maynooth. ${ }^{19}$ The respective numbers of the different religions were cited again; the Church of Ireland existed only to minister to a minority population.

Dillwyn realized that his motion could be construed as an attack on the Church of England: "Before entering on a discussion of the question," Dillwyn "wished to clear the issue from all irrelevant matter, and particularly to dispel one error--," that he had "brought the subject forward as an enemy of the Established Church in England."20 Dillwyn argued that the foundations of the two churches were completely different. The Church of England rested on, and was supported by, the good will of the English people. In that sense the Church of England was a popular church. Dillwyn noted, conversely, that the Irish church "rested on a totally different foundation," and that if it were to rest solely on the good will and consent of the people of Ireland it would collapse at once. 21 The Irish church rested solely, as far as Dillwyn was concerned, on "power" and "bayonets." 22

Dillwyn and his supporters proceeded to examine the mission of the Church of Ireland. There were, they said, two possible missions. One, that the Church of Ireland was a national church: a church established to serve the 
citizens of the country. Dillwyn declared that the definition of an "established church is one that of an establishment by the general consent of the community for the administration of religion." 23 As a national church it was a complete failure. The statistics gave the lie to the Church of Ireland as a national church. As Grant Duff noted, it was the:

Church of the great landowners, the bankers, the merchants. It is, so far as I know, the only church in Christendom of which it has been truly said that it takes for its motto 24 'I fill the rich, and the poor I send empty away.'

The proponents of the measure, as they had in 1863, derided the notion that the Church of Ireland had succeeded as a missionary church. 25 Grant Duff, in fact, argued just the opposite. Duff claimed that the Church of Ireland had "created about $41 / 2$ millions of the most determined Catholics in the world." 26

If the Irish church had failed in its official mission, was there any other reason for maintaining its ascendancy? Perhaps the Irish church could be maintained as a political bulwark of the English government in Ireland. As in 1863, this possible explanation for the Church of Ireland's existence encountered derision from those who would see its destruction. Far from being a source of stability, the Irish church was condemned as a source of weakness and dissension. Grant Duff, in explaining why Irish Catholics seemed so aggressive in comparison with 
their co-religionists in France and Spain, opined that "it is simply because the sagacity of English statesmen took care that, even after the penal laws were abolished, there should remain one grievance, which would fulfil the proverbial functions of a moderate persecution in stimulating religious zeal." 27 Dillwyn claimed that "it might be said that it [the Irish church] was instituted in order to obtain influence over the people of a country, and so to facilitate government; but if it had failed in converting the people, it must necessarily prove not an assistance but a serious impediment in the way of administration." 28 Nor was the administration of Ireland all that was at stake. If Irish grievances were allowed to continue, the very integrity of Parliament would be at stake:

He [the $O^{\prime}$ Donoghue] did not, however, hesitate to say that the effect of so persistent a refusal to redress a crying and acknowledged grievance had been to impress the great mass of people of Ireland with the idea that there was no reliance to be placed on the action of Parliament, and to cause them to regard with suspicion the man who told them that they ought to have every confidence in the wisdom and justice of the House of Commons. And when the House reflected on the length of time during which the question of the Irish Church Establishment had been under the notice of the Legislature, without any remedy being provided, they must, he thought, admit that it was not unnatural the pegple of Ireland would come to the conclusion.

The delays in granting a solution to the problem of the Irish church could only encourage the Irish to find extra-parliamentary methods of attaining satisfaction. 30 
The proponents of the measure also addressed the question of what effect a revision of the status of the Church of Ireland would have upon the Act of Union. Grant Duff pointed out that a Tory government had already weakened the act when they had amended the fourth article. ${ }^{31}$ Duff was amused by the concern shown about preserving the Act of Union against any more changes:

This exaggerated veneration for the Irish Union sounds strange in the ears of a Scotchman when he remembers how the Scottish Union fared. How? Is it possible to maintain that the temporalities of the Irish Church were considered more sacred at the time of the union with Ireland than the heritable jurisdictions at the time of the union with Scotland? And did not the heritable jurisdictions go the same road that we hope to see the Irish Establishment go?

Duff clearly felt that Parliament, for no good reason, was being very selective about how they viewed the inviolability of Acts of Union.

The issue of the Irish church was admittedly delicate and difficult. The $0^{\prime}$ Donoghue noted "that the maintenance of the Established Church in Ireland in its present condition had already been discussed with all the force, eloquence, wit, and logic which could be brought to bear upon it, and all to no purpose." 33 Arguments were made, echoing sentiments voiced in 1863, that the Irish, the international community, and inflential members of English government had all voiced dissatisfaction with the church of Ireland. ${ }^{34}$ The issue, according to the proponents of the motion, was pressing. An answer was needed urgently. The 
O'Donoghue, who had risen to second Dillwyn's motion, ended

his speech with an impassioned plea:

It was of the utmost importance to know what course Her Majesty's government intended to take on the present occasion--the noble Lord at the head of the government (Viscount Palmerston), the right hon. Gentleman and the Home secretary (Sir George Greyl, and the secretary of state for the Colonies (Mr. Cardwell) having, in published speeches, given their adhesion in every essential particular to the first part of the Mothion of the hon. Member for Swansea (Mr. Dillwyn).

If they agreed with the first portion how could they reject the latter?

If they opposed it, he was anxious to hear what reasons they would give. If they said the time was not come for action, he would ask them was the time not always come for acting with justice. He hopes Her Majesty's Government upon the present occasion would show that they were not afraid to take a just course. If they acted in the spirit which had dictated their speeches, he was certain that not only would they have a large gathering in that House, but their vote would commend itself to the great majority of the Irish people, and also to large numbers of persons in England. A vigorous, just, and prompt course taken at this particular moment would have a most beneficial effect, not only upon the State of Ireland, but ${ }_{3}$ perhaps, upon the future prospects of the Empire.

Arguments made in favor of action were to no avail.

Sir George Grey, speaking for the Liberal government,

refused to be drawn into the quagmire that was the question of the condition of the church of Ireland. Grey admitted that, "If, as a mere abstract question, I were asked to say that the present position of the Irish Church is not satisfactory, I should probably not differ much from the hon. Gentleman." 38 Grey, however, felt that more evil than good would be accomplished by questioning the status of 
to the Irish Church. ${ }^{39}$ Grey closed his speech by stating:

I am not surprised at the discontent existing from the cause I have mentioned, and I should be glad to redress it. But it is impossible to do without producing evils of far greater magnitude than those which now exist, and without involving in dissensions which would be totally destructive of peace and progress. For these reasons, believing that the subject advowed by those who have brought forward the Resolution is one which could not be attained without great mischief, being of opinion that no practical grievance exists, and that in attempting to redress the theoretical grievance, a great shock would be given to our laws and institutions, I can have no hesitation on the part of the Government in opposing the motion.

What sort of mischief was Grey afraid of? Dillwyn and Duff both stated that the measure was intended as an inquiry only; no follow-up action or legislation was mandated. 41

Yet once the government undertook an official inquiry, how could they not act upon their discoveries? Especially, as The O'Donoghue had so impertinently pointed out, many of the highest members of government had expressed dissatisfaction with the Church of Ireland. The government sought to avoid the whole problem by claiming that no real grievance existed.

But what if a real grievance had existed? What if the government was forced into action? What had Grey meant when he had talked of a "great shock" to England's "laws and institutions?" What if the government had gone ahead with an inquiry? The results of that inquiry were almost predictable: the present condition of the established Church of Ireland was unsatisfactory. What action would 
be taken? Sir George Grey had declared himself in favor of concurrent endowment. 42 concurrent endowment, however, was not what Dillwyn and his supporters had in mind. They had already stated that the established church of Ireland was a festering wound that poisoned and enraged the minds of Irish Catholics. Grant Duff condensed 300 years of English miscues and misrule into one succinct statement:

During the last 300 years, you have had three policies in Ireland. From Queen Elizabeth to William III, there was a policy of persecutions-that failed. From William III down to Catholic Emancipation, there was a policy of ascendency-that failed too. Then timidly and tentatively you turned toward general endowment, and in 1845 Sir Robert Peel took a considerable step in that direction. It soon became clear, however, that the cquntry would not follow you on that road . -

The time for concurrent endowment had come and gone. That left only disestablishment.

Debate was adjourned until May 2nd. On April 28th, in response to a question from Walpole, Dillwyn stated that he was not ready to continue with the question on the 2 nd. 44 On May 12th, in response to a query by Dillwyn, sir George Grey said that the calendar for the rest of the parliamentary session was too full, and that there was not time enough to address the issue. The debate in Parliament on the Irish church was finished for 1865 .

Gray's Motion, 1866. Many members of Parliament could not have been too shocked when, on April 10, 1866, Sir John Gray reintroduced discussion of the Irish church. Nor, by 
this time, would there have been surprise at Gray's admonition that he spoke the sentiments "of those who act with me, when I say that we are fully determined never to let this question rest until Church ascendancy is abolished, and until perfect religious equality is established in Ireland." 45 The language of the new motion was stronger than the language of the 1865 motion (just as the language of the 1865 motion was stronger than that of the 1863 motion). Gray moved "that the position of the Established Church in Ireland is a just cause of dissatisfaction to the people of that country, and urgently demands the consideration of parliament." 46 The debate on the church of Ireland had been reopened.

Gray condemned the Church of Ireland with very severe language. Gray claimed that the only "pretence" upon which the Irish church could be defended was that it was:
- . an old wrong, and old injustice, and old abuse, [that] has continued for so lengthened a period that there would be serious difficulty in removing that grievance. . . that there [are], in fact, certain established rights of injustice, and that these rights of injustice must be preserved 47 and conserved because of their long continuance. 4

Gray went on to explain that "everyman in Ireland," except those people who were intimately connected with the Church itself, "admits that the Established Church of Ireland has failed most signally, failed as to every one of the purposes for which it was imported into that country."48 Gray finished his statements of general condemnation, and said 
that, since this Parliament had seen so many new members, he would repeat some of the facts that had been used in the earlier debates. 49

Gray and the other proponents proceeded to reiterate many of the same themes that had been stressed in earlier debates. The 1861 census was again quoted. Gray and Mr. Pollard-Urquhart, using those statistics, claimed that the Church of Ireland had failed as a missionary church. In short, none of the old complaints had disappeared. 50

Neither had the argument disappeared that the Irish church was disruptive to the civil peace of Ireland. 51 Gray asked if Ireland and the Irish should be happy and equal citizens in Great Britain, or:
- . shall we have a great surging mass of discontent created, fostered, and rendered active by the continuance of unequal laws--of laws which, if they do not actually injure the person, affect the social position and the future progress in life by putting the brand of degradation and of inferiority upon one class, and givipg an odious and hateful ascendancy to the other.

Colonel Greville, who seconded the motion, invited the House to "assist in removing a cause of calamity to Ireland and the constant source of its disaffection." Colonel Greville further added that "might it not be said of England and Ireland - . that the nations are two, because the Churches are one?" 53 Disaffection of the Irish was still a major issue in the discussions on the Church of Ireland. Other issues, however, came to the fore as well. 
In this debate the proponents of the measure spent much more time answering the criticisms of the Conservatives. One argument that the conservatives used 54 was that in reality the church of Ireland was the true heir to the Catholic Church of St. Patrick. The O'Donoghue answered by claiming that it did not matter in the least whether or not St. Patrick had been a Protestant. What mattered was that the vast majority of the Irish were still Catholic and that they had never "embraced" the Protestant religion. 55 Colonel Greville argued, in response to Conservative concerns that disestablishment would affect the Act of Union, that the Parliament had already "fiddled with the Act." The first time was in 1833 when they suppressed 10 bishoprics and 2 archbishoprics; the second in 1834 when Parliament suspended "numerous dignities and benefices;" and the third time in 1838 when Parliament "extinguished" 258 of the tithes. 56

The supporters of the measure also made use of a new argument. Colonel Greville argued that disestablishment had been tried, with success, in Canada. Canada had, according to Greville, disestablished the state church for the sake of "social harmony." 57 If Parliament could give control of the church to the Canadians, who promptly disestablished it, why could not Parliament disestablish the Irish church?

Dillwyn's motions had been very tentative steps toward disestablishment. As the debates continued and more 
thought was given to what to do with the church once it was disestablished, some small differences appeared among the proponents of the measure. Sir John Gray and The O'Donoghue were for complete disendowment. The O'Donoghue claimed that the clergy would not accept church endowment and that the ecclesiastical revenues were the property of the Irish nation. 58 Colonel Greville on the other hand argued that for political reasons it was impossible for the Catholics to accept money from the state:

They would lose caste if they did. It would diminish their influence with the people and it would be a misfortune if their influence were lost; because, when the Irish people cease to have respect for the authority of religion it will not be long $_{59}$ before they throw off the authority of the state.

Mr. Pollard-Urquhart agreed that the clergy would not, or could not, accept state money, but he wondered if the money could not be spent in part in increased grants to Maynooth and to the Regium Donum. 60 Whatever differences may have appeared between some of the supporters of the measure, they were all in agreement that resolution of those differences could wait. The issue was complicated, but what was more important was "the right to worship God according to their consciences, and the right of being perfectly free and unfettered because of religious opinion." 61

The proponents of the measure were to be disappointed again. Chichester Fortescue, speaking for the government, claimed that: 
- . few will blame them [the government], because I think few will maintain that public opinion has attained so clear and so ripe a state on this subject as would enable the Government to know, first of all, what is possible, in the next place, what would be most acceptable to those who are most interested in the matter--namely, the people of Ireland, and especially the Roman Catholic people of Ireland.

Fortescue also claimed that the resolution would not be one of discussion, but would compel immediate action on the part of the Government. 63 Fortescue did say, no doubt knowing he was engaging in a fantasy, that he hoped that the church of Ireland would voluntarily give up some of its endowments--not to be given to the priests, but to be given to "some body fairly representing the Roman Catholic Church as a whole." 64

The supporters of Gray's motion did not go away completely empty-handed. Fortescue did make statements in favor of their motion that were much stronger in their support than past statements had been. Fortescue started out by saying that he confessed that he approached the "resolution personally with feelings of sympathy and concurrence." 65 He further admitted that:

If it does not now press hardly in its daily effects upon the peasantry and fairness of the country, yet (it now) influences and colours every subject of public discussion, and most deeply affects the minds of the most educated and intelligent portion of the community.

Fortescue further refused to acknowledge that any of the arguments that the Conservatives had in defence of the Church of Ireland were valid. Fortescue claimed that the 
arguments which "support and justify the existence of the Established Church in England condemn the existence of the Established Church in Ireland." 67 Fortescue ended his speech by admitting that he did not know when the time for action would come, but that he wished "it well," and that he wished it "God speed." 68

Despite Fortescue's encouraging tone, the supporters of the motion were not entirely pleased. They had hoped for some sort of tangible government support, and all they had received in return were words of potential support for sometime in the unforeseen future. Mr. Pollard-Urquhart, who followed Fortescue in speaking, allowed his bitterness over the Government's refusal to back the motion to show:

The right hon. Gentleman has said, indeed, that public opinion is not sufficiently ripe to enable any Government to take it in hand (the issue of Church disestablishment). Why, Sir, what progress could our legislation ever make if Government were never to deal with any question till they thought public opinion ripe for it?

Pollard-Urquhart went on to remind the Liberals that the Whigs had backed free-trade even when there was no public support, losing office in consequence in 1841. Yet the Whigs had been vindicated seven years later in 1848 when they were re-elected on a free-trade platform. The Government benches remained quiet for the rest of the debate.

Gray's Second Motion, 1867. On the 7th of May, 1867 , Sir John Gray brought to the floor of Parliament another 
motion with respect to the Irish church. His motion asked "that this House will, on Wednesday the 29 th day of this instant May, resolve itself into a committee to consider the Temporalities and Priviledges of the Established Church in Ireland." 70 Sir John was not overly hopeful, however, that the issue would find favor with either party:

It would seem as if the leaders at both sides of the House [shrank] from dealing with this question, which is, no doubt, one of peculiar difficulty--it would seem as if they [are] anxious to avoid dealing with it at all. . The leaders on the other side of the House do not feel disposed to take it up, possibly because they feel that they are too short a time in office. The leaders upon this side of the House do not seem disposed to take it up because they fepl that they are too short a time in opposition.

Gray hoped, however, that the House would look favorably upon his motion and go into a committee--not to endorse any particular course of action--but to come to grips with the problem of a Protestant church forced onto a predominantly Catholic nation. 72

The arguments used against the Church of Ireland were those of the previous debates. The proponents of the measure concentrated a goodly bulk of their attention on the political ramifications of the establishment. Mr. Murphy argued that the Church of Ireland had been established for political, rather than religious reasons. 73 Sir John claimed that the Irish church was a chief grievance of the Irish. Gray further attacked the members of Parliament for dragging their feet. He pointed out that Earl Russell had 
only half-heartedly addressed the issue of the Irish church at a time of serious Irish discontent. ${ }^{74}$ Gray asked Parliament if they wished church disestablishment to be carried in the same way that the issue of Catholic emancipation had been resolved:

Do the leaders mean to intimate to us who sit below the gangway that we are to get up an agitation somewhat analogous to the angry agitation which carried Catholic Emancipation . . ?

Beyond asking what it would take to move the leaders of the two parties to address the issue of the Irish church, the proponents of the motion gave dire predictions of what would happen if the Irish church was left alone. Sir John Gray quoted Sir George Lewis "in one of his most recently edited publications:"

No improvements in the material economy of the Established church, in the distribution of the revenues, or the discipline of its clergy, tend to lessen the sense of grievance arising from this source, the objection if on principle, not of degree, and nothing short of perfect equality in the treatment of all religious sects will satisfy the person whose discontentment springs from this source. The effect of the reference in question is that the whole body of the Roman Catholics in Ireland are more or less alienated from the Government, the author of their wrong, and filled with jealousy and ill will toward the more favored Protestants.

Colonel Greville, who seconded the motion, claimed that "it was the existence of this grievance and others that gave discontented agitators their influence over the people of Ireland, and if it were not for them their agitation would be without effect." 77 
Influential Liberals were coming ever closer to being in agreement with the radicals and non-conformists who favored the immediate disestablishment of the Irish church. Chichester Fortescue claimed that "every argument put forward in support of the Establishment here amounted to a condemnation of it there." 78 Fortescue agreed with the proponents of the measure that the existence of the established church was a cause of Irish discontent. Fortescue said, on the issue of discontent and the established church, "I believe that until the ascendancy which at present exists in that respect is done away with, we shall not have peace, contentment, or prosperity in the land. " 79

Despite words of encouragement, Fortescue and other Liberals did not feel that they could support the measure as a party. As serious as the discontent was, it was not nearly as bad as Irish discontent had been in the past. Fortescue claimed that the Fenian movement was not as "injurious" nor as bad as the "civil and religious war of 1798," nor was the discontent as bad as the state of Ireland 30 years before the current debate when, Carrickshock and Rathcormac. As compared with
the state of feelings which existed at those
periods, the House [can] look with satisfaction
at the support received by the Executive from the
middle and upper classes during the Fenian
disturbances. It [is] impossible to look at
these things without recognizing that the policy
of justice and wisdom on which the House entered 
a few years ago had borne fruit, and that its results ought to encourgge parliament to proceed in the same direction.

Calm, deliberate consideration was the order of the day. Fortescue argued, in agreement with Gladstone, 81 that the issue had not reached a stage at which it could be dealt with:

- - though its vast and pressing importance was becoming everyday much clearer to the mind of this country. The circumstances of Ireland, the intolerable and continued presence of sedition and disaffection in that country [calls] for 82 conscientious examination by Parliament . . 8

Fortescue said that he would "hail the day when they could arrive at a settlement of this question." 83 Fortescue, however, admitted that that day had not yet arrived and that the best he could do was give his assent to the motion as a private member. ${ }^{84}$ The proponents of the measure had come extremely close to getting some sort of official recognition for it. Yet prominent Liberals, when it came time to declare their intentions, backed away from wholehearted support for disestablishment. They were willing to support an inquiry into the subject--but only as individuals, not as a party.

The proponents of disestablishment had used several arguments in favor of their motions. They had argued that the great majority of the Irish were not Anglicans, but rather that they were Catholics, and they had argued that the church of Ireland had failed in its mission as a missionary church. More importantly, the proponents of 
disestablishment had stated that the Church of Ireland was a primary cause of Irish discontent. Further, they pointed out that Irish discontent was a threat to the legislative union between the two countries. The leaders of the Liberal Party had concurred with almost all the arguments made against the Irish church. The leaders of the Liberal Party, however, did not agree that Ireland was as discontented as the proponents of disestablishment claimed. The Liberal Party refused to take up the cause of disestablishment because they felt that the condition of Ireland did not warrant their addressing an issue that was so complicated and volatile. It was obvious that support of the Liberal Party could be had only if Ireland showed signs of pervasive discontent. 
Notes

1 William E. Gladstone, The Gladstone Diaries, ed. H. C. G. Matthew (Oxford: Clarendon Press, 1982), vol. 7, $61-62$

2 Gladstone was still a Conservative in 1845 .

3 F. S. L. Lyons, Ireland Since the Fenians (London: Fontana, 1973) 131

4 Hansards Parliamentary Debates, 3rd Series $\underline{(1830-1891)} \operatorname{LXXII}(1844): 1016$

5 Hansards CLXX (1863): 1988 .

6 Hansards CLXX (1863): 1989.

7 Hansards CLXX (1863): 1990 .

8 Requiring for protection a 21,000 man army and a 12,450 man constabulary. Hansards CLXX (1863): 1995 . 9 Hansards CLXX (1863): 1996. The 1861 Irish census was widely used in the debates on disestablishment. The census showed that, out of a population of $5,798,967$, there were 4,505,265 Catholics; 693,357 members of the Church of Ireland; 523,291 Presbyterians; 45,399 Methodists; and 31,655 others. For a brief discussion of the importance of the 1861 census see E. R. Norman, The Catholic Church, page 290

10 Hansards CLXX (1863): 1991-1992.

11 Hansards CLXX (1863): 1992 .

12 Hansards CLXX (1863): 1994.

13 That is, until the formation of the National 
Association in 1864 .

14 See page 93 below for the National Association. See also E. R. Norman, The Catholic Church, chapter 4 and page 289 .

15 "The oath prescribed in the Catholic Emancipation Act had been framed as a safeguard to the Protestant Constitution. As well as disclaiming the right of the pope to absolve subjects from their allegiance, the oath also bound Catholics to 'abjure any intention to subvert the present Church Establishment as settled by Law within this realm -.', E. R. Norman, The Catholic Church 291. See also pages $292-296$.

16 Hansards CLXX (1863): 1989. See also J. F. Maguire, Hansards CLXXI (1863): 3 .

17 When Miall introduced a motion concerning the Church of Ireland.

Hansards CLXXVIII (1865): 384 .

19 Hansards CLXXVIII (1865): 384 .

20 Hansards CLXXVIII (1865): 384 .

21 Hansards CLXXVIII (1865): 385.

22 Hansards CLXXVIII (1865): 385 .

23 Hansards CLXXVIII (1865): 385. See also page 490 .

24 Hansards CLXXVIII (1865): 451.

25 See Dillwyn, Hansards CLXXVIII (1865): 386-388.

26 Grant Duff, Hansards CLXXVIII (1865): 490.

27 Hansards CLXXVIII (1865): 388 . 
28 Hansards CLXXVIII (1865): 388 .

29 The O'Donoghue, Hansards CLXXVIII (1865): 392-393.

30 Hansards CLXXVIII (1865): 393.

31 Which dealt with Catholic emancipation. Hansards CLXXVIII (1865): 479-480.

32 Hansards CLXXVIII (1865): 490 .

33 Hansards CLXXVIII (1865): 393.

34 Hansards CLXXVIII (1865): 392.

35 That the current condition of the church of Ireland was unsatisfactory.

36 That it required the immediate attention of the Government.

37 Hansards CLXXVIII (1865): 395-396.

38 Hansards CLXXVIII (1865): 398 .

39 He even stated that the church of Ireland had been beneficial to the Catholics because without it there would have been no grant made to Maynooth. Hansards CLXXVIII $(1865): 399$.

40 Hansards CLXXVIII $(1865): 402$.
41 Dillwyn, Hansards CLXXVIII (1865): 391 . See also Grant Duff, page 453.

42 That is, the English government would pay endowments to the Catholic church. There would be two official churches in Ireland, both controlled from England.

43 Hansards CLXXVIII (1865): 452.

44 Hansards CLXXVIII (1865): 1204. 
45 Hansards CLXXXII (1866): 973.

46 Hansards CLXXXII (1866): 1008 .

47 Hansards CLXXXII (1866): 976.

48 Hansards CLXXXII (1866): 975.

49 Hansards CLXXXII (1866): 975.

50 Hansards CLXXXII (1866): $975-977$ and 1026-1027.

51 since this paper is concerned with, in part, disestablishment and the Fenians, it will bear repeating those themes that deal with discontent--of which the Fenians were the most spectacular example.

\section{2}

Hansards CLXXXII (1866): 974.

53 Hansards CLXXXII (1866): 1009 and 1015 .

54 see pages 54-56.

55 Hansards CLXXXII (1866): 1036-1037.

56 Hansards CLXXXII (1866): 1013-1014.

57 Hansards CLXXXII (1866): 1011-1012.

58 Hansards CLXXXII (1866): 1016-1037 and 1041.

59 Hansards CLXXXII (1866): 1010.

60 Hansards CLXXXII (1866): 1029.

61 Hansards CLXXXII (1866): 973.

62 Hansards CLXXXII (1866): 1017.

63 Hansards CLXXXII (1866): 1016.

64 Hansards CLXXXII (1866): 1019.

65 Hansards CLXXXII (1866): 1017.

66 Hansards CLXXXIi (1866): 1020.

67 Hansards CLXXXII (1866): 1021. 
68 Hansards CLXXXII (1866): 1022.

69 Hansards CLXXXII (1866): 1025.

70 Hansards CLXXXVII (1867): 96.

71 Hansards CLXXXVII (1867): 97.

72 Hansards CLXXXVII (1867): 105 and 110.

73 Hansards CLXXXVII (1867): 137.

74 Hansards CLXXXVII (1867): 101-102.

75 Hansards CLXXXVII (1867): 100 .

76 Hansards CLXXXVII (1867): 101.

77 Hansards CLXXXVII (1867): 111.

78 Hansards CLXXXVII (1867): 168.

79 Hansards CLXXXVII (1867): 138.

80 Hansards CLXXXVII (1867): 171-172.

81 see pages 68-69.

82 Hansards CLXXXVII (1867): 167.

83 Hansards CLXXXVII (1867): 172 .

84 Hansards CLXXXVII (1867): 172. 


\section{CHAPTER II}

THE UNSYMPATHETIC REACTION: THE CONSERVATIVES

Dillwyn's motion in 1863 met with little sympathy from either the Liberals or the Conservatives. As long as the Liberals were in power they did little to help along any schemes that involved revision of the status of the church of Ireland. The Liberals did not, however, deny that the current position of the church of Ireland was unsatisfactory. They simply did not want to involve themselves in a problem that had caused the downfall of several ministries. 1

Nor were all Conservatives pleased with the relationship between England and the Church of Ireland. Disraeli, in his speech before Parliament in $1845,{ }^{2}$ had claimed that the existence of an "alien church," along with the problems of absentee landlords and chronic poverty, were justifications for a revolution.

Other Conservatives were unhappy with the Church of Ireland as well. In 1853 Lord stanley wrote a pamphlet on the church rate question. In his diary he noted:

I inserted, tentatively, some passages adverse to the general principle of Establishment of a ecclesiastical kind: but confined this to theory, though it may be that a practical apglication to the Irish Church is not far distant.

Two weeks later, Lord stanley again noted his lack of 
satisfaction:

Moore brought on the subject of the Irish Church: Lord John strongly opposed all inquiry, or attempt at change: I did not vote, the permanent maintenance of the Irish Establishment cannot be defended: but it is reasonable and expedient to wait until the cessation of emigration shall have settled the relatiye numerical strength of the two creeds and races.

Lord Stanley's hope that the problem would resolve itself was altogether too sanguine. Nine years later the question of the relationship between England and the Church of Ireland was again making itself felt:

(Talk) with Sir G. Lewis, chiefly on points of history, not much of present affairs: the only thing he said bearing on live politics was that in his eyes the real difficulty of the day was the Irish church. While it remained there appeared no chance of the Catholics being satisfied, yet to reduce would do no good, and to abolish it wholly would be impossible, the country not being ripe for the voluntary system, and the middle classes looking on the Irish Church in particular as the defence of Protestantism. In all this I assent.

Nine months later the issue was tentatively introduced by Dillwyn.

Lord stanley's statements are intriguing. They show the general reticence felt in dealing with Irish affairs; the hope that, if enough time went by, the changing circumstances would solve the problems. In this case Stanley hoped that emigration would eventually solve the problem of having an officially established Protestant church in a land that was predominantly Catholic.

Lord Stanley, however, was not representative of the 
Conservative Party; he was very close to the Whigs in sentiment. He noted in 1864 that he felt there was little difference between Conservatives and moderate Whigs. 6 Whatever qualms he may have had about the church of Ireland, others were quick to defend its existence. When Dillwyn introduced his first motion, it was the Conservatives who most strongly opposed it.

\section{Dillwyn's First Motion - 1863}

The job of defending the Irish church fell on the shoulders of James Whiteside, M.P. for the University of Dublin. Whiteside opened his attack by questioning the motives of those who were behind the motion (despite Dillwyn's claims that he had no ulterior motives). Whiteside was convinced that this attack on the church of Ireland was really a preliminary move against the Church of England. Whiteside claimed that the "hon. Gentleman" had made "a political reputation by nibbling at the Church of England." 7

Whiteside further attacked the measure because of what he considered its faulty attempt at mollifying Irish opinion. He doubted that the Irish were that dissatisfied: "I believe that Irishmen are much less discontented and less quarrelsome than people generally in this country imagine." 8 In fact, Whiteside was amazed, given Dillwyn's statement about Catholic unrest, that he had heard nothing from the Catholic M.P.'s. Whiteside claimed that "it is a remarkable 
fact that his motion is not brought forward or suggested as far as I am aware, by the Roman Catholic Members of this House." 9

Whiteside also attacked the question of the relative strengths of the various denominations. Whiteside first claimed that the number of Protestant churches in Ireland had grown. 10 He further wanted to know the source of Dillwyn's statistics. Whiteside could not question the results of the 1861 census, but he could, and did, question the statistics for 1834 (with which Dillwyn compared the Church in 1861), since there was no census in 1834. Whiteside questioned the source and veracity of Dillwyn's information. ${ }^{11}$ Whiteside, however, knew that the 1861 census figures in themselves were damning, and tried to belittle their importance by claiming that he agreed "with Burke that it will be a bad day for mankind when great principles come to be decided by numerical majorities." 12 Whiteside attacked the measure because of its possible effects on the Union, and that "the very fact that the Church in Ireland has existed for centuries, and that it is incorporated in the constitution of the country, is a powerful argument in favor of its preservation." 13 . This argument was one which, in time, became the Conservatives strongest argument against disestablishment.

Whiteside's major argument, however, was that the Church of Ireland represented "true" religion. ${ }^{14}$ on this 
issue Whiteside felt he had his most telling point: an attack on the Church of Ireland was an attack on the accomplishments of the Reformation:

But I will add, because I do not wish to conceal it, that it is mainly to be defended because it is connected with the Reformation. It burst the fetters that enchained the human mind. It taught people to think, and shook the powers of darkness and of evil; from that moment the church of Ireland has held up the lamp of truth. It may have been obscured, but has never been quenched. 15

Despite the lack of action in 1864, Lord Stanley did note that the issue had not gone away. When he went into the smoking room in the House of Commons, he:
- found Bright, declaiming, as is his custom, to a circle of friends: Ireland the subject: he said no good would be done until the estates were divided, tenant right given, the Irish Church done away, the revenues partly secularized, partly
divided among all sects.

Despite Bright's conviction that something had to be done, no action was taken until 1865--the Conservatives had a year before they had to think about the issue of the Irish church.

\section{Dillwyn's Second Motion - 1865}

The Conservatives were more worried in 1865 than they had been in 1863. Rumors were drifting about that the whig government was going to support Dillwyn in his efforts:

There having been sidely circulated a report that ministers intended supporting Dillwyn's motion on the Irish Church, I asked Sir C. [Wood] if there wasn't any truth in it? He said, 'none,' that the subject had not even been seriously discussed, so far as he knew--that for himself he thought the Irish Establishment an abomination, and believed 
most public men did so, but to attempt to meddle with it would be madness.

wood went on to reassure stanley that "he was not aware of any intention to support Dillwyn even indirectly. Certainly no joint action would be taken by the cabinet." 18 This must have soothed some of the concerns that the Conservatives would have felt over a battle on the church of Ireland. When the measure came up for debate, however, the Conservatives had one of their more capable members, Gathorne Hardy (later Lord Cranbrook), speak against it. Hardy started out in much the same vein as Whiteside had in 1863 and claimed that disestablishment of the Church of England was the real goal. ${ }^{19}$

Hardy catalogued the defects of the measure--some of which repeated arguments made by whiteside in 1863. Hardy doubted that the Irish were that discontented: "The hon. Member for Swansea speaks of the Church of Ireland as being propped up by bayonets. Surely that is a fiction which can hardly exist even in the mind of the hon. Gentleman." 20 Hardy even went so far as to claim that the Irish peasantry looked upon the Protestant pastors as their friends. 21 Hardy, however, was not so foolhardy as to say that there was no discontent in Ireland at all. Hardy felt that the discontent in Ireland existed mainly because of their impoverishment. Hardy could, for that reason, remark, "Is it [disestablishment] to bring peace? We have been told so 
before, but it is not by surrendering principles that you can bring peace." 22

Unlike Whiteside, however, Hardy was more concerned with the effect that disestablishment would have upon the Act of Union. The Act of Union had been forged as an inseparable bond between England and the Church of Ireland. "The Union, therefore, in reference to the Church was, it seems to me, one of the most solemn obligations that was ever entered into." 23 Hardy was not rigid in his religious views. If one of Britain's colonies did not want an established church, that was their right. Ireland, however, did not have that freedom: its church was established.

Independence and freedom of action seem to me the right of the Colonial Churches which are not established, and they should only be limited with regard to the Church of England and Ireland so far as is absolutely necessary in consequence of her union with the state. That union must, to some extent, affect her liberty, but there is a large compensation in the continued recognition of a Natignal religion, and its inestimable results.

Hardy's statement did not preclude all reforms of the Irish church--as long as they were minimal. Hardy did not condone, however, an attack that threatened the existence of the church: an attack on the church of Ireland, reasoned Hardy, was an attack on the union between England and Ireland.

Gray's First Motion - 1866

The Conservatives were no happier with the 1866 measure 
than they had been with the motions of 1863 and 1865 . Their attack on the 1866 motion closely resembled their attacks on the earlier motions. Mr. Whiteside claimed that the "important majority" of Ireland was Protestant and that to disestablish the Irish church would leave this majority without any important concessions--concessions that were necessary if Protestants were to continue to govern Ireland. $25 \mathrm{Mr}$. Whiteside further argued, as did Pell Dawson, that the church of Ireland represented "true" religion. 26 But to their defense of the Act of Union they now added the issue of property. Whiteside asked Parliament if they were "aware that when you are asked to disturb the Established Church in the possession of her property, you are asked to overthrow the Act of settlement?" 27

The Conservatives did not agree with the proponents of the measure that it was all that necessary. Further, they saw disestablishment as only the beginning of Catholic demands. The Conservatives queried when Catholic demands were going to stop. Whiteside quoted Lord Plunkett, who had promised that Catholics in Ireland would not attack the established church if they were granted emancipation. 28 The Conservatives, in the person of Mr. Pell Dawson, even accused the catholics of forging signatures on petitions against the established church, which, Dawson claimed, "were known to be in many instances in the same handwriting."29 Finally, the conservatives doubted that 
the Irish were all that dissatisfied. 30 The Conservatives argued that those Irish who were dissatisfied, the Fenians, were not concerned with the issue of the church establishment. Mr. Whiteside made the disingenuous argument that the Fenians did not attack the established church because the Fenians knew that the church "dealt fairly and equitably with her tenants." 31

Gray's Second Motion - 1867

The debate of 1867 was the fourth time that the church of Ireland had been under attack in Parliament. The Conservatives, like the radicals and Liberals, were starting to sound like well-worn records. They claimed that the Church of Ireland was the true church, that an attack on the Church of Ireland was an attack on private property, and that the question was much too complicated an issue for Parliament to address. They even doubted that there was an ascendancy in Ireland. Sir Frederick Heygate stated that "as far as [I] can tell there [is] no ascendancy in Ireland." 32 The Conservatives denied that any problem existed--they came very close to denying that there was an established church in Ireland.

By 1867 the Conservatives could no longer claim, however, that there was no discontent in Ireland. They belittled the idea that the church of Ireland was a legitimate and serious grievance. Mr. Chatterton, the Attorney General for Ireland, claimed that it was only a 
grievance (and a "sentimental" one at that) of the catholic clergy and certain other agitators "who sought to make for themselves political capital."33 sir Frederick Heygate was more precise in his assessment of the problem of discontent:

It [is] a mistake to imagine that the disturbances which had recently occurred in Ireland [have] for their origin religious grievances. It [has] been over and over again stated authoritatively that the Fenian movement has no connection with Religion, and . - the Fenians themselves, as aु body, [are] dead to all religious considerations.

The Conservatives felt that the fact that Ireland was discontented was all the more reason to hold onto the established church: "It should not be forgotten that in all the disloyalty that [has] prevailed during the last two years not one member of the Church of Ireland [has] been suspected . . "35 The Conservatives did not believe that disestablishment could placate Irish discontent in the form of Fenianism. In fact, the Conservatives were loathe to destroy an establishment whose members were demonstrably loyal to the status quo in Ireland. 
Notes

1 J. L. Hammond, Gladstone and the Irish Nation, 2nd ed. (Hamden: Archon Books, 1964) 6 .

2 see above, pages 19-20.

3 J. R. Vincent, ed., Disraeli, Derby, and the Conservative Party. Journals and Memoirs of Edward Henry Lord Stanley (New York: Barnes \& Noble, 1978).

4 vincent, stanley 31 May $1853,107$.

5 vincent, Stanley 27 July $1862,190$.

6 Vincent, stanley 24 July 1864,222 . Vincent wrote in his introduction that "his diaries show him to be a disinterested, liberal English nobleman," xvii.

7 Hansards CLXX (1863): 2004 .

8 Hansards CLXX (1863): 2006 and 2018 .

9 Hansards CLXX (1863): 2007. The reason for Catholic silence was most likely due to the oath they had taken not to bring up issues dealing with the Act of Union. Gathorne Hardy noted that, when the question of repeal of the oath came up, that "the Oath is nothing in itself, but the object of repeal is to free the hands of those who are bound by it from attacks on the Church." Alfred Erskine Gathorne-Hardy, Gathorne Hardy, First Earl of Cranbrook

(New York: Longmans, 1910) 29 May 1865, 173.

10 Hansards CLXX (1863): 2014 .

11 Hansards CLXX (1863): 2014 .

12 Hansards CLXX (1863): 2009. 
13 Hansards CLXX (1863): 2007-2008. See also 20152016

14 Hansards CLXX (1863): 2009-2010.

15 Hansards CLXX (1863): 2020.

16 stanley, 11 April $1864,213$.

17 Stanley, 16 March $1865,229$.

18 wood to stanley. Stanley, 16 March $1865,229$.

19 Hansards CLXXVIII (1865): 402-403.

20 Hansards CLXXVIII (1865): 416 .

21 Hansards CLXXVIII (1865): 416 .

22 Hansards CLXXVIII (1865): 416 .

23 Hansards CLXXVIII (1865): 413 .

24 Hardy to Mowbray. Hardy-Erskine, page 172. The letter was in response to one from Mowbray asking Hardy to run for a seat at oxford.

25 Hansards CLXXXII (1866): 1044 .

26 Hansards CLXXXII (1866): 1050 and 1023.

27 Hansards CLXXXII (1866): 1063. See also 1052 and 1060

28 Hansards CLXXXII (1866): 1052-1053.

29 Hansards CLXXXII (1866): 1025 .

30 Pell Dawson, Hansards CLXXXII (1866): 1024 .

31 Hansards CLXXXII (1866): 1061 .

32 Hansards CLXXXVII (1867): 115 .

33 Hansards CLXXXVII (1867): 133-134.

34 Hansards CLXXXVII (1867): 117 . 
35 Sir Frederick Heygate, Hansards CLXXXVII (1867): 115. 


\section{CHAPTER I I I}

\section{"THE TIME IS NOT RIGHT": \\ GLADSTONE'S REACTION TO EARLY DISESTABLISHMENT MOTIONS IN PARIIAMENT}

Gladstone introduced his motions to disestablish the Church of Ireland in 1868. Gladstone had had ample opportunity since 1863 to act on the disestablishment issue. At any point during that time he could have declared himself in favor of action; he could have pushed disestablishment to the forefront of parliamentary consideration in much the same way he had forced the Palmerston government to adopt a new parliamentary reform measure. The fact is, he did not do so.

Of all the leading Liberals he was considered the one most likely to adopt disestablishment as an issue. In 1864 he was reported to have had a conversation in which he called the church of Ireland a "hideous blot" and he felt that it was one of two issues on which reform was possible. 1 In 1865, sir C. Wood told Lord Stanley that no support for Dillwyn's motion was planned, but that "he would be sorry to answer for what Gladstone might or might not say on any question (laughing)." 2 Precisely what Gladstone would or would not do was a complete unknown--Gladstone was a mystery 
to many of those around him. ${ }^{3}$ Disraeli and Lord Stanley were not quite sure in 1866 what Gladstone was going to do on the question of Ireland, although they felt some action was imminent:

He (Disraeli) hears that Gladstone has a 'sensation measure' ready, of what kind he does not know, but believes it to relate to Ireland: whether payment of priests, or reduction of Irish Church endowments, or some great project of buying up the Irish railroads.

Long before Gladstone had made up his mind to promote action on disestablishment, those around him, especially Conservatives, felt that he was planning some sort of action.

Despite expectations that he would do so sooner, Gladstone did not declare himself in favor of active reform for Ireland, including the question of the Church of Ireland, until late 1867.5 Before we get to Gladstone's decision to act on the question of the Irish church, we must understand why in the preceding years he did not act upon his convictions.

Dillwyn's First Motion - 1863

Dillwyn's motion in 1863 was Gladstone's first parliamentary opportunity to declare his opinion on the condition of the Irish church. He felt that the whole question should be dropped. ${ }^{6}$ Gladstone further claimed that "the business of the session was . . pressing," and that he did not "think there was such a general desire on the 
part of the House to proceed with the debate that the Government should give up the time at their disposal for that purpose. 7

John Maguire, evidently misunderstanding Gladstone's statement, felt that Gladstone was mistaken and that there was a very great desire on the part of Ireland for a solution to the problem. ${ }^{8}$ Gladstone responded that he "did not presume to say whether or not there was a strong feeling in Ireland on the question, but only that there had been no general manifestation of a desire in the House for a debate on it." 9

The proponents of the measure may have been disappointed, but, given the history of the issue, they could not have been too surprised. Gladstone's response was well in step with good solid Liberal/Whig thinking. He did not say that the measure was, in itself, wrong. He did not question the logic behind the measure. He simply stated that he felt that there was no general sentiment in the House of Commons to deal with the issue. He completely ignored the question of Temporalities.

\section{4}

Gladstone, in 1864 , called the Church of Ireland a "hideous blot", and went on to tell Enfield that he thought an inquiry was "unnecessary and a waste of time."10 Gladstone's remark to Enfield is much stronger in its condemnation of the Irish church than was his statement to 
Parliament in 1863--he was prone to making strong comments. For example, in May of 1864, Gladstone, who was making a speech in favor of the extension of the franchise, commented that there was no reason in the world why every man should not be within the "pale" of the constitution. 11 This comment was taken to mean that Gladstone was advocating universal male suffrage. Gladstone, however, later said that he wasn't sure what all the commotion was about, and that it was not "a deliberate and studied announcement." 12 In his conversation with Lord Enfield on the Church of Ireland he was also only voicing his opinion. Like his speech on parliamentary reform, his comments on the established church were neither deliberate nor studied. As future events were to show, Gladstone was not yet ready to undertake the disestablishment of the Irish church. Gladstone was giving vent to his dissatisfaction with the established church; he was not raising the cry of battle.

\section{Dillwyn's Second Motion - 1865}

Gladstone's speech on Dillwyn's second motion is among his more famous. John Morley, Gladstone's biographer, declared that with that speech "Mr. Gladstone made the first advance upon what was to be an important journey."13 Certainly, reviewed in retrospect, it was the beginning of Gladstone's concern with Irish reform and was a major step toward disestablishment, even if Gladstone was as yet unaware that he was embarking on a crusade that lasted the 
rest of his political life.

Gladstone rose to speak immediately after Gathorne Hardy ${ }^{14}$ and stated that he found himself in agreement with Dillwyn's sentiments: "For my part I confess that I cannot refuse to admit the truth of the first, and perhaps the most important of these propositions that 'the present position of the Irish Church Establishment is unsatisfactory." "15 He reiterated arguments made by the proponents of the measure.

Gladstone, however, felt that he could not support the measure. He had divided the question into two parts: 1) that the then current arrangements were unsatisfactory, and 2) that they required the immediate attention of the government. The first proposition he agreed with; the second he did not. He felt that the question was "not so much a question for the present as for future consideration." 16

Gladstone believed that Parliament "ought to decline to follow him [Dillwyn] into the lobby, and declare that it is the duty of the Government to give their early attention to the subject. . ."17 Gladstone felt that the time was not ripe, for a variety of reasons, to disestablish the Irish church. To begin with, the "country" (and he most likely meant England) was not ready to address the question of disestablishment. Parliament, elected in 1859, had not been returned on the issue of disestablishment, and 
Gladstone felt that before Parliament could undertake such an arduous task the electorate should be consulted. ${ }^{18}$ Another problem was that disestablishment and the issue of the endowments were extremely complicated. The question of what to do with the endowments was very complex and needed a great deal of study. ${ }^{19}$ Finally, Gladstone felt that the members of Parliament should not support Dillwyn's motion,

- - because if we gave a vote to that effect, we should be committing one of the gravest offences of which a Government could be guilty--namely, giving a deliberate, a solemn, promise to the country, whigh promise it would be out of our power to fulfill.

Gladstone admitted that the condition of the Irish church was unsatisfactory. He was not, however, willing to commit himself to taking any action against it. Gladstone had condemned the church in very harsh words in both his conversation with Lord Enfield in 1864 and in his speech before Parliament in 1865. Gladstone really could not help being so condemnatory. As R. Shannon has pointed out, "Gladstone was not comfortable unless he could base his proposed action upon the foundation of some simple, large, grand first principle . . "21 His intentions, however, were moderate despite the effect his words had on those around him. 22 Gladstone's speeches were often as incautious as his actions were cautious.

Gray's Motions, 1866 and 1867

Gray's motion in 1866 came at a bad time. Gladstone and the Liberals were extremely busy with the pending 
electoral reform legislation and probably did not have enough time to devote to the issue of the Irish church. The constraints on Gladstone's time, however, did not prevent him from dealing with the issue of Irish discontent. Early in 1866. Gladstone made a speech in favor of the suspension of habeas corpus in Ireland. 23 He also did some reading on the question of Irish discontent. 24 He did not, however, study the issue of the Irish church. The nature of his reading showed a growing awareness of the Irish inquietude. The Russell government (Palmerston had died in 1865) fell on the issue of electoral reform. The issue of reform did not, however, die with the Liberal government. After the failure of the Reform Bill, the English countryside erupted into a flurry of angry "monster" meetings held to demand electoral reform from Parliament. The conservative government of Derby found itself with a potential crisis on its hands. The Liberals, now sitting in opposition, were waiting for a chance to drive the conservatives from power. Many Englishmen were aroused and demanded that they be given the vote. If not for the actions of Disraeli, the Conservatives might not have lasted more than a few months. Disraeli realized that electoral reform was inevitable and he saw no reason why the Conservatives should not get the credit for extending the franchise. The violence in England had not been serious, but it was sufficient to convince the Conservatives that some sort of electoral reform was 
necessary

The question of reform was debated into the early part of 1867. Disraeli's initial bill was extremely conservative, and the Liberals set out to amend it into a bill more to their liking. Much to the Liberals' frustration, Disraeli went along with all their amendments. Consequently, the 1867 Reform of Parliament Act was much more liberal than the Liberals' first bill in 1866. Over the years, steady pressure on Parliament had netted the proponents of electoral reform a carefully considered and rather conservative bill. Widespread discontent after the failure of the bill created a bill that neither party had imagined possible in 1865. The Conservatives had been shocked into realizing that electoral reform was a necessity by the intensity of discontent in 1866. Would widespread discontent have to infect Ireland before either party would take up the issue of disestablishment?

By April of 1867 most of the substantive issues dealing with electoral reform had been dealt with, which left the rest of that year to consider other questions. The proponents of church disestablishment used the relative lull in parliamentary business to bring forth yet another motion to address the problem of the Church of Ireland. Gladstone did, on this occasion, feel inclined to speak on the issue. He spoke in favor of Gray's motion, but was not, as he told the House, entirely happy in doing so. Gladstone told Gray 
that he felt difficulty in supporting the measure, not because he questioned the "soundness of the main proposition," but because, in a refrain that was becoming all too familiar, he questioned "whether the time had come when a practical plan upon this subject can with advantage be submitted to Parliament." 25 Gladstone was worried about the complicated nature of the issue and was not sure that it had been considered long enough to be effectively dealt with by Parliament.

Gladstone was happy, however, that Gray's motion called for the formation of a committee. Gladstone had opposed the earlier measures because they had called for a consideration by the whole House to deal with the problem of the Church of Ireland. Gladstone had felt that the House as a whole could not even tentatively deal with such an important issue. For that reason, Gladstone had spoken against Dillwyn's motions (in 1863 and 1865) even though he had expressed sympathy with the sentiments that lay behind the measures. Gray's motion in 1867 called for the formation of a committee. Gladstone felt that the issue of what to do about the Irish church could be discussed calmly within a committee, whereas if the whole House took up the issue, great "mischief might be done by a premature attempt at legislation." 26 He then turned his attention to the arguments of the Conservatives. 
Gladstone started his attack on the Conservatives by claiming that the catholics could not be held captive to the views of the long dead Lord Plunkett. Gladstone argued that the Catholics had respected the existence of the Irish church and had done so with "great patience." 27 He further added that, even if Catholics were prevented from attacking the Irish church because Lord Plunkett had accepted the Church of Ireland as a necessary part of the Union, Gladstone, as an Anglican, was under no restrictions in that sense. Gladstone added that, if the roles were reversed and the Catholic church was established in Protestant England or Scotland, Parliament and the English would be working with all their might to change that situation; and, Gladstone added, they would be right in so doing. 28

Gladstone also attacked various other notions advanced during the debate in defense of the church of Ireland. He was skeptical of the idea that the Irish church was necessary because it administered to the majority of the "highly educated" citizens of Ireland. Gladstone commented that, if those "gentlemen" were so highly skilled and educated, they should be able to "subsist on their own means and not on means supplied by the public from sources which are not legitimate." 29 Gladstone further felt that the Conservatives were wrong in their belief that the voluntary system would not work for the church of Ireland in the countryside (the Conservatives did admit that the voluntary 
system would probably work in the towns). He pointed out that the voluntary system had worked quite well for the Roman Catholic Church, and, he added, he assumed that it would work just as well for the members of the church of Ireland. 30 Gladstone was particularly amused by Heygate's argument that, if the Irish church was disestablished, the Protestants in Ireland would increase their proselytism among the Catholics. Gladstone took Heygate's argument and turned it against the Conservatives. He argued that if Heygate was correct the Conservatives had no choice but to vote for the measure. Gladstone followed Heygate's argument to its logical conclusion: if the church represented truth, and if the removal of the church of Ireland created a feeling of missionary fervor in the Protestants, the result of which was the conversion of more Catholics to the Protestant faith, then the best thing for the Protestant religion would be the removal of the Church of Ireland. ${ }^{31}$ He was most puzzled with the Conservatives' contention that the disestablishment of the Church of Ireland would be the cause of even greater civil strife. Gladstone found strange the threat of greater civil disobedience:

That threat is very often used in these discussions, but what is the meaning of it? It seems to me to mean this. There are present a large body in Ireland who have not obtained equality, and, because they have not, there is an absence or a partial absence of religious peace; but there is another party in Ireland who have more than equality--who have got advantages and 
priviledges--and if they are put on an equality they will protest against it and make more disturbance becaugse they have equal treatment with their neighbors.

Gladstone doubted that such a party existed in Ireland.

Gladstone was in agreement with Gray and the proponents of the motion on the issue of the establishment as a source of civil discontent. Gladstone claimed that he was in agreement with Gray when Gray claimed that the "state was finding fuel for the Protestant Churches in Ireland," to which Gladstone added that he was afraid that the "state is not only finding fuel for the Establishment, but fueling a great many other flames." 33 Gladstone summarized his feelings on the relative merits of disestablishment on the civil welfare of Ireland:

If we look to Irishmen for the same allegience [sic], if we call upon the community of Ireland to support and sustain us in applying restrictive measures to the disaffected $\cdot$. do not deny 3 that reciprocity is the essence of justice itself.

He fully believed that disestablishment was both a reward and inducement to the Irish to continue their union with England.

Gladstone was not against all establishments. He outlined three instances in which he felt that an establishment was correct and desirable. The first was on the basis of truth:

That is one ground on which an Established Church may be maintained; but if you maintain the Established Church in Ireland on the ground of truth, you cannot at the same time maintain and 
educate a priesthood who teach the pegple that the truth is not be found in that church.

The second instance in which an established church merited support was if it ministered to a majority of the population. The third instance was if the church was the church of "the mass of the poorer portion of the population." 36 Not even the Conservatives could argue that the bulk of the poor Irish were Protestant; the Conservatives had, in fact, argued that the church of Ireland should be maintained because the bulk of the productive and wealthy members of Irish society were Protestants.

Gladstone closed his statements by repeating the point that the time for reform would soon be at hand:

I think the hon. Member for Longford is correct in his anticipation that the time is not far distant when the Parliament of England, which at present undoubtedly had its hands full of other most important business and engagements, would feel it its duty to look this question fairly and fully in the face; and I confess that I am sanguine enough to cherish a hope that, though not without difficulty, a satisfactory result will be arrived at, the consequences of which will be so happy and pleasant for us all that we shall wonder at the folly which has so long prevented it being brought about.

He had come as close as he could to supporting the measure without taking it under his wing and adopting it as his own. Gladstone and many other influential Liberals, however, voted for the measure, which went down to defeat by a vote of 195 to $183 .^{38}$ 
Gladstone was moving, albeit slowly, to the conclusion that action would have to be taken with respect to the Church of Ireland. He accepted all the arguments advanced by the proponents of the measure. The vote had been close, and the only possible way the balance could be tipped would be if Gladstone, Russell, or some other member within the inner circle of the Liberal Party (such as Chicester Fortescue) adopted the measure for the Liberals and led the battle in Parliament.

Gladstone's willingness to speak in terms of first principles tended to get him into trouble with his own party. The other leaders of the Liberal Party feared the effect that his words would have upon the rest of Parliament. Conversely, the Conservatives never trusted Gladstone. Some felt that Gladstone was more interested in his own personal power than he was in addressing the reform of the Irish church. Despite Gladstone's willingness to talk of first principles, his motives were not that much more different than those of his colleagues in the Liberal Party •

Gladstone's speech in 1865 had caused consternation for both Liberals and Conservatives alike. Viscount Palmerston, the Prime Minister, had heard rumors that Gladstone intended to speak as an "individual" member. Palmerston attempted to stop Gladstone and sent him a message asking if it was possible for a member of the 
government to speak as an individual member:

I understand that you propose to state tomorrow on Dillwyn's Motion about the Irish Church your personal views upon that Matter, as an individual but not as a Member of the Government--I do not know what your personal views on the matter are, but is it possible for a Member of a Government speaking from the Treasury Bench so to sever himself from the Body Corporate to which he belongs, as to be able to express decided opinions, or to abstain from acting upon those opinions when required to act as a Member of theुg Government taking Part in the Decision of the Body? ${ }^{39}$

Gladstone ignored Palmerston's note and spoke anyway.

The Conservatives were ready with their analysis of

Gladstone's motives. Mr. Whiteside, the member for the

University of Dublin, and later a Chief Justice, expounded on two possibilities for Gladstone's partial support for Dillwyn's motion. His first attack on Gladstone dealt with Gladstone's reasons for holding back complete support from Dillwyn's motion. Whiteside claimed that he remembered a speech by Gladstone in which Gladstone had stated that the time for parliamentary reform was not at hand because the issue was not within the purview of "practical politics." Whiteside stated that:

I am confirmed in the opinion by his speech to-night, that his object was to lay the foundation of another scheme, a policy of another and not very distant day, when he might be able to say the time had come, and a change of feeling had been provoked out of doors that wouldoenable him to do then what he fears to do now.

Whiteside also suspected that Gladstone was buying time until he could better control the party. Whiteside 
felt that Gladstone's speech was a cowardly ruse:

Fundamental Acts of Legislature are not to be got rid of in that manner anymore than the fundamental institutions of the Empire are to be placed in danger, not indeed by any present Act, not by any present motion, but by laying the foundation and sowing the seeds of that future policy which will be adopted when the noble viscount is no longer at the heqad of the Government to restrain or direct it.

In both cases Whiteside felt that Gladstone, in a most cynical fashion, was waiting for the most opportune moment to spring the issue of disestablishment on an unwary House of Commons.

How perceptive is Whiteside's analysis of Gladstone's motives? His reasoning that Gladstone was waiting for Palmerston's death or resignation is unsatisfactory. Whiteside, in all probability, knew nothing of Palmerston's letter to Gladstone. Consequently whiteside did not know that Gladstone was more than willing to go his own way even when asked not to. Gladstone had, in fact, forced the issue of parliamentary reform on an unwilling Palmerston, 42 and, had he felt sufficiently motivated, probably could have forced Palmerston to accept reform of the Church of Ireland as well.

Whiteside's argument that Gladstone did not feel the time was suitable to bring the issue forward took on a veneer of cynicism. According to Whiteside, Gladstone merely wanted to misdirect the attention of the House while he prepared the ground for an attack on the church 
establishment in Ireland. Stripped of Whiteside's cynicism, however, Whiteside's statement is not too far off the mark. Three years later, in 1868, Gladstone claimed that the "question was not within the range of the practical politics of the day..." 43

There were other reasons for Gladstone's reticence.

In a letter to Robert Phillimore (February 1865), he noted that the Irish church was not being challenged:

It exists, and is virtually almost unchallenged as to its existence in that capacity; it may long (I cannot quite say long may it) outlive me; I will never be a party knowingly, to what I may call frivolous acts of disturbances, gr to the premature production of schemes of change.

Gladstone later admitted that, "Had any man said to me, 'How soon will it come on?' I should have replied, 'Heaven knows, perhaps it will be five years, perhaps it will be ten." 45 Gladstone, in 1865, had no idea when he felt the issue would be ripe for action.

Gladstone's reluctance to deal conclusively with disestablishment before 1868 was due to ambivalence over the practical political effects of the measure. Abstract justice was not a sufficient reason to prompt Gladstone and the other Liberals into action. Gladstone was loathe to engage in any hasty action that threatened the existence of the Church of Ireland and the domestic and political tranquility of England.

Why did Gladstone give a speech that could be construed to be in favor of a revision in the status of the 
Church of Ireland? Why did he make a favorable statement and then turn around and say that the time for action was not yet at hand? It seems likely that Gladstone was attempting to put the Liberal Party on notice that, at some point in the future, events might deem it necessary to take up the issue of the Irish church. In a sense Gladstone was attempting to help define the future course of the Liberal Party. In his conversation with the Duke of Enfield, Gladstone had told Enfield that he thought "it would not do to go to a dissolution without some proof that they were really the Liberal party."46 Enfield was even more confounded when Gladstone had expressed his personal wish that the "present cabinet should fall, on the ground that it had grown indolent and feeble, and wanted some years of opposition to give it new life." 47

Gladstone's speech in favor of the intent of Dillwyn's motion had immediate consequences: he lost his seat at oxford. The seat was most likely lost because, for the first time, ballots could be mailed, and Gladstone had incurred the wrath of the clerical graduates with his speech on the Church of Ireland. 48 Gladstone, however, then stood for South Lancashire, and in another of his more famous speeches claimed that he came before them "unmuzzled." Once unmuzzled, however, he did not approach the question of the Irish church; he attacked the question of parliamentary reform. 
$\underline{1867-1868}$

In 1868 Gladstone gave notice of his intent to bring before Parliament various motions that dealt with the Irish church. ${ }^{49}$ Gladstone's motions in 1868 represented a triumph for the supporters of disestablishment. What had changed? In 1867 Gladstone had been willing to give support to a measure that would create a parliamentary committee to look into the problem of the Irish church, albeit reluctantly. 50 Gladstone's speech in 1867 had reflected his caution and concern that precipitate change was to be as feared as injustice. Yet in 1868 Gladstone was ready and willing to disestablish the church of Ireland.

In order to understand why Gladstone changed his mind, and why he decided to rally the Liberal Party around the issue of church disestablishment, we must turn our attention to the condition of Ireland in the 1860s. We must see how British perceptions of Irish discontent changed. The step from a committee to full-blown legislation on the Irish church was more significant than it first appears. The establishment of a committee was how the British, and Gladstone, preferred to address important and complicated issues. In the calm deliberation of the committee some sort of compromise could be worked out, and minimal damage done to the British constitution. Gladstone's call for legislation in 1868 was an attempt to head off a problem 
that had, in the perception of the English, become much more serious. Finally, we must understand the effect the Fenians had upon the British imagination, and their role in convincing the English that something had to be done. 
$\underline{\text { Notes }}$

1 Conversation between Lord Enfield and Lord Stanley, 24 July 1864 , Stanley 222 .

$2 \operatorname{sir}$ C. Wood to Lord Stanley, 16 March 1865, Stanley 229.

3 See Stanley, 12 May 1864,216 . See also $217,228-$ $229,232,252,269$ and 346.

4 Disraeli to Stanley, 30 Jan. 1866, stanley 245.

5 John Bright, The Diaries of John Bright, ed.

R. A. J. Walling (New York: William Morrow \& Co., 1931), 30 Nov. 1867,313

6 In response to The O'Donoghue's request for an adjournment of the debate. Hansards CLXX (1863): 2076 .

7 Hansards CLXX (1863): 2076.

8 Hansards CLXX (1863): 2076-2077.

9 Hansards CLXX (1863): 2077 .

10 Enfield to Stanley, 24 July 1864, Stanley 222 .

11 R. Shannon, Gladstone (Chapel Hill: University of North Carolina Press, 1984) 508.

12 Shannon 508-509.

13 Morley 141.

14 see pages 53-54.

15 Hansards CLXXVIII (1865): 431.

16 Hansards CLXXVIII (1865): 392 .

17 Hansards CLXXVIII (1865): 434 .

18 Hansards CIXXVIII (1865): 431. 
19 Hansards CLXXVIII (1865): 433.

20 Hansards CLXXVIII (1865): 434 .

21 Shannon 510 .

22 Shannon 510: "Accordingly he proceeds to cut down his great first principle by limitation after limitation until, for all practical purpose, the merest shred of it is left behind."

23 See pages $117-120$.

24 See Gladstone, Diaries, vol. 6, Jan. 31-Dec. 31, 1866, pages 409-489. Some of the material he read included A Glance at the Irish Question, "The Evils of Ireland Considered," and $A$ Contribution to an Inquiry into the State of Ireland.

25 Hansards CLXXXVII (1867): 121.

26 Hansards CLXXXVII (1867): 123 .

27 Hansards CLXXXVII (1867): 122 .

28 Hansards CLXXXVII (1867): 123.

29 Hansards CLXXXVII (1867): 123.

30 Hansards CLXXXVII (1867): 126.

31 Hansards CLXXXVII (1867): 127.

32 Hansards CLXXXVII (1867): 126.

33 Hansards CLXXXVII (1867): 128 .

34 Hansards CLXXXVII (1867): 130.

35 Hansards CLXXXVII (1867): 129.

36 Hansards CLXXXVII (1867): 129.

37 Hansards CLXXXVII (1867): 130-131. 
38 Hansards CLXXXVII (1867): 182.

39 P. Guedella, ed., Gladstone and Palmerston (New

York: Harper and Brothers, 1928) 326-327.

40 Hansards CLXXVIII (1865): 483 .

41 Hansards CLXXVIII (1865): 483 .

42 Magnus 160-161.

43 William Gladstone, "A Chapter of Autobiography," in Gleanings of Past Years (London: John Murray, 1879) vol. 7, 97-151. In this pamphlet he explained why he had not acted upon Dillwyn's motion in 1865, and he attempted to show the development of his thought since the publication of his book, The Church in Its Relations With the state.

44 Morley 141-142. This was written just a month before his speech before Parliament on Dillwyn's motion. 45 Gladstone, "Chapter" 134. 46 Enfield to Stanley, 21 July 1864, Stanley 222. 47 Stanley, 21 July 1864, 222. 48 Magnus 171.

49 Hansards CXC (1868): 1974.

50 See Hansards CLXXXVII (1867): 121 . 


\section{CHAPTER IV}

\section{THE FENIANS}

The problems that plagued the relationship between Ireland and England go far beyond anything the Fenians did. The majority of the Irish had long felt some sort of antipathy toward the English. The English had responded to expressions of Irish discontent, when it flared up, with a mixture of legislation, repression, and a nagging sensation that, underneath it all, they really did not understand what the Irish wanted. Reform, it seemed, always followed upon the heels of evident discontent--such as Catholic emancipation and repeal of the Corn Laws. Even O'Connell, who preferred constitutional action over violence, had found it necessary to use the threat of violence to carry his Irish reforms through Parliament. Ever since O'Connell's death in 1847, Ireland had been relatively quiet. With the formation of the Irish Revolutionary (or Republican) Brotherhood (IRB) and the Fenians in 1858/59, and the subsequent formation of the National Association in 1864 , the Irish were again agitating for change in Ireland.

The IRB was founded in Dublin on March 17, 1858, by James Stephens. The Fenian Brotherhood was formed in the United States in April of 1859 by James Mahoney. ${ }^{1}$ The 
English considered both groups to be one and the same, and at times it was hard to tell the difference between the two. The stated goal of the IRB was the overthrow of the English government in Ireland and the establishment of an Irish republic. The American organization was originally founded to provide money and other support to the Irish Fenians. 2 The American Civil war interrupted the activities of the American organization and for the first few years both organizations were relatively quiescent.

In 1863, the Fenians established a newspaper, The Irish People. ${ }^{3}$ The paper was founded by Thomas clarke Luby (proprietor), Jeremiah O'Donovan Rossa (manager and publisher), and John O'Mahony (editor). The paper was rather strident in its tone and was closed down by the government in 1865. The Fenians planned an uprising for 1865 when it became apparent that the American Civil War was about to end. The Fenians hoped that, once Irish-American soldiers were freed from their duties in the united states, they would be able to provide experienced leadership and money for the rebellion. The leader of the Fenians, James Stephens, was arrested and the rebellion failed to materialize.

The failure of revolt in 1865 caused a break in the Fenian movement. The Americans split from the Irish organization and removed James Stephens as their "head centre." The Irish movement itself split into two competing 
groups, and the Fenians remained disorganized for the rest of the 1860s. The suspension of habeas corpus in Ireland in 1866 drove the Fenians either underground or out of the country altogether. Some of those who left transferred their activities to England where some of the larger cities had significant Irish populations. Although there were some abortive risings in Ireland in 1866, none of them did much more than illustrate the efficiency of the governmental forces in Ireland.

Eighteen sixty-seven, however, was to be in some ways a banner year for the Fenians. Although they failed in their attempt to gain access to the arms at Chester Castle, and their attempt to liberate two prisoners from clerkenwell prison ended with the death of 12 innocent people--without freeing the two prisoners--the Fenian movement managed to capture the British imagination as it never had before. The execution of three Fenians convicted in a killing at Manchester elicited a sympathetic response in Ireland; the death of 12 persons in the rescue attempt at clerkenwell enraged English opinion.

The attempts by the English to suppress the Fenian movement did not entirely succeed. Only when the failure of suppression became manifest to the English did they seriously start to consider addressing Irish grievances. The Fenians had focused British attention on the plight of the Irish, but the three major grievances of the more vocal 
Irish--tenant rights, disestablishment and education--were of little concern to the Fenians. Only when the Fenians threatened to acquire popular support in Ireland were the English willing to consider Irish grievances.

The Catholic Church and the Fenians

Officially the Catholic church condemned the Fenians. Archbishop Paul Cullen ${ }^{4}$ attacked the Fenians in an 1865 pastoral :

As to what is called Fenianism, you are aware that looking on it a compound of folly and wickedness wearing the mask of patriotism to make dupes of the unwary, and as the work of a few fanatics or knaves, wicked enough to jeopardise others in order to promote their own sordid views, I have repeatedly raised my voice against it since it first became known at the time of M'Manus's [sic] funeral four years ago and that I cautioned young men against promising or swearing obedience to strangers with whom they were altogether unacquainted, putting themselves at the mercy of plotting spies and treacherous informers and risking their lives and liberty and endangering the lives of others in attempting to carry out projects, hopeless in themselves, which doing no good to any class, might involve the country in ruin and bloodshed. Would to God that more attention had been paid to such friendly admonitions. If they had been listened to we would not now have to regret that so many young men are suffering the hardships of prison and their families overwhelmed with affliction, whilst their seducers are far away from danger, laughing at the simplicity of their dupes and enjoying the wages of iniquity.

cullen found fault with the Fenians on several points. 6 For one, they were revolutionary in their ideas. Cullen claimed that the Fenians "preach up socialism, to seize on the property of those who have any." 7 Cullen considered 
the Fenians as the natural result of the movements in

liberalism and rationalism. 8

Many of the parish priests, however, were caught in a real dilemma. The problem was, as Bishop Keane pointed out, that the priests were losing ground with their parishioners:

The great question of the day is that of

'Fenianism.' It is destined to exercise an extraordinary influence on the future relations between priests and people. . For some years past, several complaints were made by the people against what they called the inactivity and neglect of the priests. In plain words, it was said over and over again, 'that the priests don't care about us any longer. They and the upper class Catholics who expect places are well enough off, and they no longer feel for the suffering of farmers and working people.' This language and sentiment have prepared many to adopt . - conspiragy against a government that refused redress.

Keane further added, "if once the masses throw off the respect they have always felt for their priests, then will come the real Irish difficulty for England and for all concerned." 9 There was a fear among the bishops and archbishops that the Irish were turning away from their priests, and turning to other organizations that promised, if not a solution to their outstanding grievances with England, at least a fight against English presence in Ireland. In fact, priests who were either too condemnatory toward the Fenians, or who had been educated at Maynooth, the state-controlled school, were sometimes ignored and shunned :

When the priests condemned Fenianism in the confessional and refused the Sacraments to persons 
connected with it, many Fenian youths of cork gave up going to Confession to priests who had been educated at Maynooth, but some of them confessed to priests brought up in foreign seminaries . . . Maynooth priests, being educated at the expense of the state, are suspected of being more or less in the English interest.

Nor were all the clergy necessarily against the Fenians. Father Lavelle, a Catholic priest, was noted for preaching that Catholics had a right to revolution. 11

Father Lavelle's actions were essentially ignored by Bishop McHale, who refused to take any concrete action against the errant priest. Cullen vented his frustrations against McHale to Archbishop Keely:

I hope Dr. McHale will after the last letter take some steps against Lavelle. It is too bad to oblige the Holy see to occupy itself so often with that unhappy priest. One word from Dr. McHale two years ago ordering Lavelle to stay in his parish, and not act as vice-president of the St. Patrick's Brotherhood, would have saved himself and that priest from great evils.

Cullen. McHale and Lavelle all represented the three basic stances that the Irish Catholic clergy could take toward the Fenians: hostility, indifference, and support. The Catholic hierarchy was technically against all secret societies that in some way advocated abandonment of the traditional political and social values in favor of the more neutral liberal state. In this sense, the Catholic church feared the Fenians and their call for a secular Irish republic. The problem was that as long as the Irish remained discontented and the English dragged their feet on reform, the Church would continue to lose 
support in favor of those persons who promised an end to Irish suffering. The priests who worked at an intimate level with the Irish people felt acutely the pull of the dual loyalties of the Church and of their flocks. The longer the English delayed reform, the more willing the priests became to support those with extreme solutions to Irish discontent.

The English and the Irish Catholic Church

The English, for their part, quite often viewed the Irish priests as being meddlesome, especially when it came to politics. Cardinal cullen, who roundly condemned the Fenians, was seen by some Englishmen as being quarrelsome:

I wish, tho' of course in vain, that some check could be put upon cullen. I told the Pope that he was the bitter and pertinacious enemy of the English government and he never misses an opportunity of doing mischief . . It is really too bad that this viper cullen should be permitted to create difficulties in addition to those which already exist. - I shall be glad if in gentle language you could convey to the Cardinal

(Antonelli) and Manning the utter disgust

[emphasj̧̧ his] we feel at the conduct of cullen and Co.

The English found it necessary to work with the Catholics in Ireland. One of the easiest ways for the English to do that was to attempt to get the Vatican to apply pressure on the Irish Catholics. Lord Stanley wrote in his journal in 1852 that his father wishes "to lay before the court of Rome the conduct of the Irish priesthood: and to obtain a condemnation of their 
proceedings from the highest spiritual authority." 14 The English government used the same method in the $1860 \mathrm{~s}$ to try to keep Catholic priests from supporting the Fenians. In a series of conversations with Cardinal Antonelli, Odo Russell (the British representative in Rome) expressed his regret that the "Roman Catholic clergy in Ireland had not during the last 20 years opposed secret societies and revolutionary organizations of part of their flock, which culminated in Fenianism."15 A month later Russell returned to tell Antonelli that he had "received reliable information according to which the priests in many places in Ireland had joined the Fenian movement." 16 Antonelli, much to his own regret, was forced several days later to ask odo Russell to see him:

His holiness had confirmed my [Russell's] statements by private letters which had just reached him from Ireland. The evil, however, was happily limited to one or two cases only of disobedience and the pope had already caused the erring priesty to be reminded of their duties

The English did not entirely trust the Catholic priests; yet they were forced to work through them to try and stem the tide of Fenianism. Despite being, officially at least, on the same side of the question with reference to the Fenians, each mistrusted the other. The Vatican considered "fenianism [sic] a punishment from heaven for the revolutionary policy of Great Britain on the continent."18 As long as Irish discontent remained unaddressed, the 
Catholic church in Ireland remained a tenuous ally at best.

\section{The English and the Fenians}

Although the Fenians had been formed in 1858 , their first real noticeable appearance in Ireland was at the 1861 funeral of the Young Irelander, Terence Bellow MacManus. Macmanus, who had died in the United States, was exhumed and brought back to Ireland for burial in December, 1861 . Although the Fenians played a relatively minor role in the funeral itself, it was at this time that they finally came to the notice of the Irish by their boisterour demonstrations claiming Macmanus as one of their own. 19 However, the Fenians did not come to the notice of the English government until the next year (1862). Sir George Grey, the Home Secretary, admitted on the floor of the Commons that they (the government) had not known of the existence of the Fenians until 1862, at which time they were "few and inconsiderable." 20 The Fenians did not remain insignificant for long.

By 1863 the Fenians showed signs of increased activity. It was in that year they founded their newspaper, The Irish People. The paper proved to be of immense significance because it was "largely responsible for transforming Stephens' movement into a major phenomenon in Irish public life in the mid $1860^{\prime}$ s." 21 publication of the newspaper helped to spread the Fenian movement throughout Ireland. 22 
In 1863 the English also became aware of the potential threat of Fenianism in the United States. In October of 1863 the New York Mercury published an article--reprinted by newspapers in Ireland and Britain--that created the impression of a "very powerful Irish-American enterprise geared to winning Irish independence and ready to roll." 23 In November 1863, the Fenians held their first convention in Chicago, which again was widely publicized in the papers in Ireland and Britain. By early 1864, the authorities in Ireland were on the lookout for Fenians. 24

The threatened invasion of Ireland by American Fenians did not materialize in 1864. The Americans were involved in the Civil War, and a great number of American Fenians were involved in the fighting on both sides. The Fenians in Ireland, while waiting for the help promised them from America, kept busy promoting their cause. Both Stephens and O'Donovan Rossa toured Ireland and Great Britain drumming up support for their organization.

Eighteen sixty-four also saw the emergence of two organizations that competed with the Fenians for dominance over the future direction of Irish politics: the Irish National League and the National Association. The National League was founded on January 21,1864 . The goal of the League was "the restoration of a separate and independent legislature," and included in its membership The O'Donoghue, the M.P. for Tipperary land later in 1865 the M.P. for 
Tralee), and A. M. Sullivan, the editor of the Nation. 25 The National Association was formed in late 1864 to provide a "constitutional" organization that was to present to Parliament solutions to the three most pressing Irish grievances: church disestablishment, land tenure, and education (in the form of state-supported denominational schools). As E. R. Norman has stated, "the National Association of Ireland was one of the more happy results of Fenian organization, for it was established to provide an alternative, safe and constitutional means of securing the redress of Irish grievances." 26 The Fenians, the National League and the National Association all competed with each other for leadership in Irish politics. The struggle for dominance in 1864 was largely won by the Fenians:

Throughout most of 1864 and all of 1865 , normal political activity (in Ireland) was paralysed by Fenianism as by a spectre. The belief that they had in their midst a secret revolutionary army of unknown strength (with powerful allies across the Atlantic) about to throw the country into indescribable turmoil left most of the inhabitants of Ireland without any stomach for politics.

The Fenians, the United States and the English, 1865-66

All along the English government had worried about the close connection between the United States and the Fenians. The Government's suspension of the Habeas Corpus Act in 1866 was in large part motivated by their fear of the Americans. 28 
The government was afraid that once the Union Army in the United States was disbanded, large numbers of Irish-American Fenians would return to Ireland to fight against British rule. In April of $1865 \mathrm{Mr}$. Whiteside asked, on the floor of the House, the Under Secretary of State for Foreign Affairs, Mr. Laylard,

whether the Foreign office has received despatches or any information relative to statements lately published in this country to the effect that encouragement has been given by eminent political individuals in the United states to a confederacy of Fenians designed to attack Canada, to invade Ireland, 2 and to make war, when required, upon England?

Mr. Whiteside, in particular was referring to an earlier article from the Times which he read aloud to parliament. The article claimed that,

On the 6 th of March, 1864 , a report of a meeting of the Executive Committee of the Fenians at Chicago appeared in the sunday Mercury, which circulates largely among the Irish in this city, which stated that 'the Committee had received letters of encouragement from hundreds of prominent men in the country, including the Postmaster General, Mr. Montgomery Blair, Secretary Seward, Governor Yates (of Illinois), Mr. Speaker Colfax (of the House of Representatives), Colonel Mulligan, and hundreds of offigers in the army and navy of the United States.'

In addition he noted that the Times had reported that the Fenians had held a convention on December 26,1864 , in which the Fenians claimed that "it was the duty of the American Government to declare immediate war against England." 31 
Mr. Laylard responded that he had been in

correspondence with the government of the United states and that there were "only two facts mentioned which required official notice on the part of Her Majesty's Government." First, that Colonel J. H. Gleason had been given leave from the Army of the Potomac for the purpose of attending a meeting (that was unspecified), and, second, that the Attorney General of Louisiana had been present at a meeting of Fenians. The American government had responded that Colonel Gleason had been due a leave, and that there was no law against his attending a meeting of the Fenians. Mr. Laylard further reported that "Mr. Steward . . stated that the Attorney General of Louisiana was not responsible for his acts to the Government of the United States, but only to the particular state of which he was Attorney General." 32

The suspension of habeas corpus in 1866 created a whole new set of problems for the governments of Great Britain and the United States. Even before the suspension of habeas corpus, there was the potential for trouble because Irish-Americans were being arrested by the Irish authorities. On November 11, 1865, Captain Fanning, who had been an officer in the Tenth Ohio Volunteer Infantry, wrote a letter to secretary of state seward complaining that he had been unjustly arrested. His letter serves as a model for much of the correspondence on the issue of 
Americans arrested in Ireland. After being released from his duties in the American army, he travelled to visit friends in Ireland. He reached Dublin on the 16th of september. On the 2nd of October he left Dublin to visit relatives at Ballinamore, in County Leitrim:

I reached the town of Killeshundra on the third of October and while waiting to change horses, was arrested by Sub-Inspector valentine of the constabular or rural police, my baggage searched, my pistol, one round of ammunition for the same, with a few caps, taken from me, and myself and Lieutenant McNeff, of the same regiment, handcuffed and thrown into jail at Cavan, regardless of our solemn protest against such an offense being offered to an American citizen journeying through this place. I was incarcerated for seventeen days without trial at the instance of the police...

When I threw off my allegiance to Victoria, the Queen of England, and put myself under the aegis of the United States, I felt such a thrill of exultation on changing the degrading status of a mere subject to the proud one of citizenship, as co̧ulid not have been known to even the Roman of old.

The case of Captain Fanning illustrates the problems faced by Great Britain in attempting to stifle the Fenian movement. The English found it necessary to be extremely wary of strangers roaming the Irish countryside. That many of those strangers were Americans caused additional problems. The arrests of Irish-Americans raised the question as to which country had jurisdiction over the detained persons. The English did not recognize naturalized citizens, and felt that Irish-Americans were still British subjects. The government of the United States, on the other hand, 
did consider them American citizens. The suspension of the Habeas Corpus Act created a flood of complaints on the part of arrested Irish-Americans. The American consul in Ireland, Mr. West, was kept busy sorting out the claims of those who asked for the protection of the American government. 34

The Fenians in America had realized that the only way a successful rebellion could occur in Ireland was if Great Britain was involved in a war. Fenian activities in the United States complicated an already serious situation. Relations between the United States and Great Britain had been exacerbated because of the Alabama claims. The suspension of habeas corpus and the internment of Irish-Americans threatened to raise larger issues of naturalization and citizenship. Both countries behaved decently and the problem, as far as the British were concerned, had been resolved. They were able, albeit temporarily, to stem the tide of Fenianism in Ireland. The United States was happy because, within a few months after the suspension of habeas corpus, all Americans had been released.

Suspension of Habeas Corpus

The end of the Civil war in the united States brought an increasing number of Irish-Americans to Ireland and, according to Sir George Grey, the danger of Fenianism had increased alarmingly in consequence. ${ }^{35}$ Through 1865 the 
Liberal government of Palmerston insisted on dealing with the Fenians by the usual legal means available. On September 19, 1865, Government forces in Ireland seized both the leaders of the movement and closed down their newspaper, The Irish People. 36

The use of normal legal channels was not enough and, on February 17, 1866, Sir George informed Parliament that it was his sad duty to introduce a bill that would suspend the Habeas Corpus Act in Ireland. Sir George claimed that in "making the motion" he was doing so with a "deep sense" that it was the government's duty to ask Parliament for the "additional power" to:

put an effectual check on a wicked and widespread conspiracy which now exists in Ireland, and to afford protection to the loyal and faithful subjects of Her Majesty in the country.

Sir George went on to state that the "Fenian conspiracy has lately assumed proportions, a form, and an organization which could hardly have been expected a short time ago." 38 Charles Adams, the American ambassador to Great Britain, reported to william Seward, Secretary of state, that he had learned:

from several sources that the uneasiness and discontent in Ireland are not thought to have been diminished by the conviction and sentence of the offenders who have been brought to trial. The Fenian organization (in Ireland) is affirmed to be spreading in every direction, carrying with it many of the more intelligent class of the tenantry, and even compegliling the acquiescence of some of the priests. 
The suspension of the Act of Habeas Corpus in Ireland was necessary, or so the British government thought, for a variety of reasons. The English felt that Ireland was rapidly becoming ungovernable. Lord Wodehouse, the Lord Lieutenant for Ireland, wrote to Grey, telling him that "I have little hope of pacifying in the alarm, which is doing most serious injury to every interest here, without seizing the agents who are busily employed all over the country, sowing sedition and organizing the conspiracy." 40 Grey felt that the Fenians themselves were contemptible, but that they had the potential of gaining influence over the people of Ireland. 41 In addition, the probable longterm effects of Fenian influence were thought to be equally disastrous. He felt that the outcome of an insurrection, and he had no doubt that the English would win, would be "bloodshed, massacre, and the other crimes which the people usually commit in the first moment of an insurrection." 42 Finally, if the Fenians were not stopped, industry in Ireland would be paralyzed, capital would no longer flow into the country, and development of Ireland's resources would be checked. 43

The proposed bill was to be in effect for six months and was to expire on the first of september. It would give Dublin Castle the right to "detain such persons as he the Lord Lieutenant] - . shall suspect of conspiracy against Her Majesty's Person and Government." 44 The bill passed all 
three readings in both houses on the 17 th. Charles Adams made note on Parliament's hast in his dispatch to seward:

Sir: The event of the week has been the application of ministers to Parliament for a suspension of the habeas corpus in Ireland. The reason given for this strong measure is the spread of the Fenian organization, in spite of all the efforts made to check it by ordinary means. The explanations were made simultaneously in both houses on Saturday, an unusual day for transactions of other than mere formal business, and necessary measures were passed with a rapidity believerd to be unexampled even in the worst preceding cases.

Adams in fact suspected that the authorities in Ireland had started rounding up suspects even before the bill had been officially passed into law: "There is reason to believe that the necessary sanction was scarcely passed through its forms, before hundreds of suspected men were swept into prison. . " 46 Indeed, the authorities in Ireland had jumped the gun, and "hours before they could have received confirmation of a formal enactment they had moved against scores of suspects." 47

The Fenian threat had provoked the English to act. At first the English had been content to allow the law to take its normal course. The rapid spread of Fenianism, despite the arrests of its leaders, forced the English to suspend the Act of Habeas Corpus. It is ironic that reform of Irish grievances met so much resistance in Parliament, while on the other hand the English were capable of moving so quickly when they needed to strengthen the forces for repression. 
1867 - Chester Castle, Manchester, and Clerkenwell

The effect of the suspension of the Act of Habeas Corpus worked, in some ways, as well as the English could have hoped. Irishmen who had been associated with the Fenian movement in Ireland, if they were not already in jail, had either fled the country, gone underground, or completely quit the movement. As one historian noted, "the suspension of habeas corpus wreaked havoc on Fenianism in Ireland, shifting the odds in favor of the authorities." 48 The suspension of habeas corpus was not lifted after six months, and in four more acts the suspension was continued. ${ }^{49}$ The initial success of the authorities in Ireland calmed the English people, and the Illustrated London News could write in January of 1867 , in a tone of restrained optimism:

The general gloom which enveloped 1866 was not relieved by the error of our domestic politics . . To the disquiet which this question excited (parliamentary reform) must be added the apprehensions awakened by the Fenian conspiracy. In the earlier part of the year raids into Canada, in the later threatened insurrection in Ireland, exhibited at once the astounding folly, the malignity, and the pertinacity of the discordant materials of which that combination consists. Its bark, however, was worse than its bite. In America, the enthusiastic gallantry of the volunteers, backed by the loyalty of the United States President, quickly scattered the buccaneering expedition; in Ireland, the suspension of the Habeas Corpus Act, the judicious firmness of the Administration, and the skillful distribution of the military prevented the plot from maturing into rebellion; but, both in the colony and at home, it was a gratuitous afd vexatious cause of public anxiety and expense. 
The optimism of the Illustrated London News was to be short-lived. The Fenians in Ireland had been suppressed, but there were Fenians in England who were willing to take up the cause.

In February of 1867 , the Fenians planned a raid to capture the large depot of arms at Chester. Once the arms were seized, they were to be shipped over to Ireland. In anticipation of the raid, the Fenians began to congregate in large numbers in the town. Through the efforts of an informant by the name of John Joseph Corydon, the authorities were aware of the plans of the Fenians, and the police armed themselves and strengthened their numbers with volunteers and reinforcements. 51 The show of force intimidated the Fenians, who dispersed into the English countryside. The event, as one historian has noted, "was in a sense a non-event in that it ended in anti-climax and undramatic failure." 52

of much greater significance than the attempted raid at Chester Castle was the rescue of two Fenian prisoners at Manchester. The Fenians planned to rescue two of their brethren: Colonel Thomas J. Kelly and Captain Timothy Deasy. In the rescue attempt on September 18 th, a policeman, Sergeant Charles Brett, was accidentally killed. Five men were arrested for the shooting of Brett. Of the five, three were condemned to death and were executed on November 23rd. The three executed men, William Philip 
Allen, Michael Larkin and Michael O'Brien, joined the pantheon of Irish martyrs.

The imprisonment and the execution of the "Manchester Martyrs" stirred up a storm of controversy. It was not as if the Government (at this time under the Conservatives) did not know what effect political executions would have upon the Irish. Lord Stanley had argued against the execution of a Fenian prisoner back in May of 1867 because the execution would only turn the prisoner into a martyr and help the Fenian cause. 53 From the very beginning, however, Gathorne Hardy, the Home Secretary, was determined to punish those responsible for the killing at Manchester. On September 20th Hardy noted that the newspapers "have a short account of the Manchester outrage \& the Times is as the public will be ready for strong measures." 54 Hardy further felt that not to punish the Fenians would be wrong since England would "never endure that such an event should happen unpunished . . " 55 If Hardy had ever been uncertain of what course to take, his interview with Queen Victoria confirmed him in his desire to see the Fenians executed: "Since lunch I have had a long interview with the Queen who was very gracious \& cheerful. She spoke of Fenians--ldid not approve of more mercy) . . " 56

A storm of protest swept over both England and Ireland. In England John Bright led a delegation to the Home Office to convince Hardy that execution was too severe. 
Rebuffed in his efforts, Bright wrote in his diary two days before the execution that the "Tories know little mercy; terror is their only specific." 57 on the day after the execution, Bright noted that "the hanging of the 3 men at Manchester has caused some excitement." 58

In Ireland demonstrations and marches were held in favor of the executed Fenians. On December 1st a "large procession" of 2,500-3,500 people was held in Manchester: "as the procession marched past the New Bailey, where the gallows had been erected, they gave three cheers for Allen, Larkin and Gould." 59 In Cork, on the 1st also, a procession was held that was estimated to have attracted $12,000-15,000$ marchers. 60 The largest procession was held in Dublin on Sunday the $8 \mathrm{th}$. The Annual Register estimated that there were less than 16,000 marchers, although it seems likely that there were anywhere from 20,000 to 30,000 marchers. 61 More important than the demonstrations themselves were some of the people who expressed a degree of sympathy for the Fenians. O'Neill Daunt, certainly no friend of the Fenians, called the executions "judicial murder" and claimed that "the murder of those three men will widen the breach between this country and England."62 cullen allowed priests to pray for the Manchester men, and even allowed them to say private masses for them. ${ }^{63}$ Characteristically, he couldn't help but take a dig at the English and wrote in a letter that "the English have given large sums to Garibaldi to assail 
the Pope - . now as they have done to others so it is done to themselves." 64 Even more ominously, at the head of the procession in Killarney was the M.P. for Tralee, The O'Donoghue.

A third event, one that shocked the English public, occurred at Clerkenwell prison on Friday the 13th, 1867. Ricard O'Sullivan Burke had been arrested by the English for his part in the Manchester rescue. The Fenians decided that they would attempt to rescue Burke and another Fenian by the name of Casey. ${ }^{65}$ The plan was relatively simple. The rescuers were to roll a keg of gunpowder up against the prison wall (Burke and Casey would be doing their regular hour of exercise in the prison yard). A white ball was to be tossed over the wall to warn the two prisoners that their rescuers were setting off the charge. Casey and Burke would then wait away from the area where the hole was going to be blown and, in the confusion caused by the explosion, they would rush through the breach in the wall to their freedom. The first attempt on December 12 th was unsuccessful: the fuse refused to stay lit. On the 13 th the Fenians tried again. This time the fuse lit and blew a hole in the wall "twenty feet wide at the base and sixty feet wide at the top, killing 12 persons in the surrounding neighborhood and wounding close to a hundred."66 Burke and Casey, in their cells at the time of the blast, were not freed. 
The effect of the Clerkenwell explosion on the English was profound. The English throughout the countryside became paranoid and started to imagine that they, too, were to be the victims of Fenian terrorism. Rumors of Fenian activity abounded throughout England. Lord Stanley noted in his journal that Hardy had,

received a multitude of Fenian communications. One informant speaks of 155 Fenian and republican clubs in London alone, all unknown to the police. Several announce projects for blowing up the House of Parlt [sic], and assassinating the Queen. Another reported plan is to seize the $P$. of $W$. [sic] [Prince of Wales] on his way to or from Sandingham [sic]. From Philadelphia comes a story of an association whose object is to hire houses in various parts of London, fill them with combustibles, and set them on fire at the same time. A Fenian has been heard to threaten the burning of the theatres when full, and the destruction of public buildings. The police report on Fenian evidence, that three men are told off to assassinate Ld. D(erby) [sic], Hardy and me. Monck telegraphs (and this is the most serious, as being in some degree authenticated) that a ship is to sail for Dieppe ostensibly, really for the Bristol channel, from New York, with a parfty on board whose object is to murder the Queen.

Throughout early 1868 papers such as the Illustrated London News constantly ran articles on the visit of the Prince of Wales to St. Bartholomew Hospital where many of the victims were staying, or they ran articles describing the recovery of the victims. ${ }^{68}$ In addition, the Illustrated London News ran articles on the activities, or supposed activities, of the Fenians and of the fearful responses of various communities. They reported, for instance, the theft of 60 revolvers and 1,500 rounds of ammunition in Cork. They 
reported that special constables were sworn in at the Woolwich arsenal. 69 The Illustrated London News was able to report that the "special Constable movement seems to have pervaded the whole of the United Kingdom. The provincial papers, both English and Scottish, are filled with reports of magisterial meetings to enroll defenders of law and order." 70

The most common reaction to the clerkenwell explosion was horror and disgust. The incident at clerkenwell divided American Fenians. Some of them condemned the senselessness of the violence. 71 More importantly, the clerkenwell explosion helped those who were chronically anti-Irish. William Murphy was typical of the hysterical anti-Irish, anti-Catholic sentiment that fed off of such events. Throughout the 1860 s he lectured for a group called the Protestant Evangelical Mission and Electoral Union. 72 Murphy's speeches were vitriolic and quite often accompanied by violence. In one town, Wolverhampton, the violence was so intense that the mayor asked Murphy not to hold any more meetings. When Murphy refused, the mayor was forced to swear in special constables. ${ }^{73}$ The combination of the incident at Clerkenwell and the 1868 elections provided Murphy with a volatile situation that he used to attack those who advocated Irish reform. The "no-popery" cry that was raised, though much more limited than the defenders of the established Irish church hoped, was in part due to 
the combination of discontent in Ireland, the incident at Clerkenwell, and the speeches of Murphy. 74 Murphy called the demands of the Catholics "impudent" and claimed that they "were reaping the fruits of the Catholic Emancipation Act." 75

The events at Manchester and Clerkenwell captured the attention of the English as no other Fenian activities had before. Manchester aroused Irish sympathy for the Fenians; Clerkenwell horrified the English. The situation was becoming completely unmanageable. 
Notes

1 T. W. Moody et al., A New History of Ireland, vol. VIII (Oxford: Oxford UP, 1976) 332-333.

2 see Introduction, page 15 , note 4.

3 Moody, New History, vol. VIII, 336.

4 He was made Cardinal in 1866--the first Irishman made Cardinal. Moody, New History, vol. VIII, 338.

5 Peadar MacSuibhne. Paul Cullen and His Contemporaries (Naas: Leinster Leader Ltd., 1961) 397-398.

6 For a good treatment of the Catholic church and the Fenians, see Norman, Catholic Church 86-134; and, Donal McCartney, "The Church and Fenianism," in Maurice Harmon, ed., Fenians and Fenianism (Seattle, University of Washington Press, 1970) 14-27.

7 MacSuibhne 399. There was a connection between the Fenians and Karl Marx's International Workers movement, but it was rather tenuous and never amounted to much. Patrick Quinlivan and Paul Rose, The Fenians in England 1865-1872 (New York: Riverrun Press, 1982) 153-156 and 169-170.

8 Macsuibhne 399.

9 Norman, Catholic Church 99.

10 The observation of O'Neill Daunt. Norman, Catholic Church 99 .

11 He came to prominence in Parliament for his involvement in a political riot. See Hansards CLXX (1863): 2022 . 
12 Norman, Catholic Church, 102.

13 Noel Blakiston, The Roman Question (London: Chapman and Hall, 1962), Clarendon to Russell, 357-358. Antonelli was Secretary of state for the Vatican.

14 Stanley, 2 Aug 1852, 79.

15 Blakiston 325-326.

16 Blakiston 326 .

17 Blakiston 327 .

18 Blakiston 348 .

19 See Macsuibhne 398.

20 Sir George Grey on the motion to suspend the Act of Habeas Corpus. Hansards CLXXXI (1866): 669 .

21 R. V. Comerford, The Fenians in Context (Dublin: Wolfound Press, 1985) 109.

22 Especially in Limerick. Comerford 109.

23 Comerford 110 .

24 comerford 110.

25 Comerford 100.

26 Norman, Catholic Church 135.

27 Comerford 109.

28 For the suspension of habeas corpus, see pages 9699.

29 Hansards CLXXVIII (1865): 891 .

30 Hansards CLXXVIII (1865): 890 .

31 Hansards CLXXVIII (1865): 890 . 
32 Hansards CLXXVIII (1865): 891. See also Foreign Relations of the United States (New York: Kraus Reprint Corp., 1965) 1865, vol. II, 67-103.

33 Foreign Relations, 1866, vol. I, no. 1621. Seward to Adams, 29-30.

34 See, for example, Foreign Relations, 1866, vol. I, $36-112$

35

Hansards CLXXXI (1866): 69-70.

36 Hansards CLXXXI (1866): 670 .

37 Hansards CLXXXI (1866): 668 .

38 Hansards CLXXXI (1866): 668 .

39 Foreign Relations, 1866 , vol. I, no. $1132,58-59$.

40 Hansards CLXXXI (1866): 677 .

41 Hansards CLXXXI (1866): 673 .

42 Hansaras CLXXXI (1866): 675 .

43 Hansards CLXXXI (1866): 680 .

44 Hansards CLXXXI (1866): 661 .

45 Foreign Relations, 1866 , vol. I, no. $1158,69$.

46 Foreign Relations, 1866 , vol. I, no. $1158,69$.

47 comerford 133.

48 comerford 133 .

49 New History, vol. VIII, 338. The Liberal

government had fallen in 1866 on the issue of parliamentary reform. From mid-1866 until 1869 the Conservatives under Derby (and in 1869 under Disraeli) were in power. 50 London Illustrated News 5 Jan. 1867: 1-2. 
51 Quinlivan and Rose 16-23.

52 Quinlivan and Rose 16.

53 Stanley, 22 May $1867,309-310$.

54 Gathorne Hardy, Diary of Gathorne Hardy, Later Lord Cranbrook, 1866-1892: Political Selections, ed. Nancy E. Johnson (Oxford: Oxford UP, 1981), 20 Sept. 1867, 49-50.

55 Hardy, Diary, 20 sept. 1867, 49-50.

56 Hardy, Diary, 22 sept. 1867, 49-50.

57 Bright, 21 Nov. 1867, pp 312-313.

58 Bright, 24 Nov. 1867, 312-313.

59 Annual Register $(1867): 163$.

60 Annual Register (1867): 163 .

61 Annual Register $(1867): 163$. Comerford says that there were 30,000 marchers, page 147. Quinlivan and Rose claim that there were 20,000 marchers with 50,000 spectators, page 86 .

62 Norman, Catholic Church 120. See also Comerford 148.

63 See his earlier attitude toward the Fenians, pages 85 and 87 .

64 Norman, Catholic Church 121.

65 Quinlivan and Rose 82.

66 Quinlivan and Rose 87.

67 Stanley, 28 Nov. $1867,276$.

68 Illustrated London News, Jan. 4, 11 and 18, 1868 .

69 Illustrated London News, Jan. 11 and $18,1868$. 
70 Illustrated London News, Jan. 11, 1868.

71 Quinlivan and Rose 97.

72 see Chapter 3 in Donald C. Richter, Riotous

Victorians (Athens: Ohio UP, 1981).

73 Richter 37 .

74 In fact, Norman feels that Murphy helped defeat

Gladstone in the election in South-West Lancashire.

Norman, Catholic Church 347 , note 3 .

75 Annual Register (1867): 79. 


\section{CHAPTER V}

GLADSTONE, THE FENIANS AND CHURCH DISESTABLISHMENT

By late 1867 it became apparent to Gladstone that Ireland was significantly discontented, discontented enough for him to go beyond personal expressions of support to promote disestablishment. After the events at Manchester and clerkenwell, reform of the three major Irish grievances (land, church, and education) became necessary. Gathorne Hardy, the Conservative Home Secretary in 1868, noted that the Government "was ready to consider disestablishment, but proposed the postponement of the question until the next parliament." 1 Gladstone himself admitted in a letter to Earl Grey that recent problems in Ireland had convinced even the Conservatives of the necessity of reform:

I further admit that Ld-Derby's Government must in substance have shared this impression, when before we as a party had proposed anything [emphasis mine], they thought it their duty to propound a policy for Ireland, including in it the questions of Church, Land, and Education.

Once the Derby/Disraeli government fell in 1868, however, the Conservatives refused to countenance any change in the religious status quo in Ireland. The Conservatives were convinced that the Liberals had been influenced by the Fenians. The Conservatives were skeptical about the effects Irish reform would have on Fenianism. 
The Quarterly Review, a conservative magazine, felt that:

When the suspension of the Habeas Corpus Act in Ireland was moved, Mr. Bright considered it a fitting opportunity to enlarge on the wrongs of Ireland, to suggest that the remedy for Fenianism was to be found in the alterations of the tenure of land, and in the abolition of the Irish Church . . Whatever may be the merits of Land Reform or Church destruction, they have nothing to do with Fenianism. It will run its course whether land be placed in new hands or left in old ones, whether cardinal or archbishop rule in Dublin. It is a National, not a religious nor an agrarian movement, its hatred is not so much $\beta_{f}$ English institutions as of England itself.

The Quarterly Review was half right. There was little direct link between the Fenians and church disestablishment in that it was not one of their demands. Furthermore, the Fenians were motivated by a blind and passionate hatred of England. While the Quarterly Review could not find any connection between Fenianism and church disestablishment, Gladstone and the Liberals could.

Gladstone's speech in 1865 was made at a time when the Fenians were just beginning to make their presence felt. 4 The Fenians in Ireland were one of several groups at that time that were purporting to speak for Ireland. By early 1865 they had successfully made their presence felt, and were beginning to gain adherents among the Irish in Ireland and Great Britain. The American Fenians had also, by early 1865, gained the attention of the English. The English realized that, once the American Civil War was over, the American Fenians would attempt to act on their plans to free Ireland from Great Britain. Fenians were not, in 1865, 
a direct threat, and while Gladstone was willing to admit to the justice of church disestablishment, he was skeptical of the seriousness of Irish discontent. 5

\section{In 1866, Gladstone, for various reasons already}

discussed, declined to address Gray's first anti-church motion. 6 The Fenians in 1866, however, had become a greater threat than they had been in 1865. The spread of the Fenian movement startled many in Parliament. The Queen, in her opening address to Parliament, noted that a "conspiracy" had "appeared in Ireland" that was "adverse alike to Authority, Property, and Religion . . ." 7 "Fortunately," she continued, the Fenians were "disapproved and condemned alike - . without Distinction of Creed or Class . . " and that "the Constitutional Power of the ordinary Tribunals had been exerted for its Repression, and the authority of the Law had been firmly and impartially vindicated." 8 Eleven days later the Liberal government was sufficiently worried to pass the first of four habeas corpus suspension acts.

Gladstone spoke in favor of suspension of the Habeas Corpus Act. He believed, as did many Englishmen, that the Fenian movement was essentially American in origin. He noted that they were not "wanting in funds for its support," and that the suspension of habeas corpus was necessary since under the regular laws, and with all their money, the Fenians were able to quickly bail themselves out of jail. ${ }^{9}$ 
In a later debate he stated, "it may be perfectly true--and is, unhappily, too true--that Fenianism in the main, under the means by which it is supported, is a thing imported by America." 10 Gladstone also noted that the measure had not been intended at the beginning of the parliamentary session because "the emergency was not at that time of that grave character which alone would have justified us in taking an extreme step in regard to it.. . "11 Gladstone also refused to take seriously Bright's statement that, if Ireland could, she would "unmoor" herself and "move at least 2,000 miles to the west." 12 Gladstone claimed that the Irish could not be too unhappy with the suspension of habeas corpus since none of them had declared themselves against it. ${ }^{13}$ Gladstone continued:

We have the unanimous consent of the House expressed to this effect, and expressed by every member who comes from Ireland that this conspiracy deserves the disapproval and condemnation which have already been bestowed upon it by everyone who can claim to represent either the property 14 the morality, or the religion of the country."

Gladstone still believed that Irish grievances should be attended to--in due time. Gladstone asked Parliament to "give anxious consideration . . to every subject connected with the welfare of Ireland." "But," as Gladstone added, "do not let these subjects which, important as they are, are less important than the duty of today,.. . to interfere with the discharge of that duty." 15 
In August of 1866 he rose to speak on a renewal of the suspension of habeas corpus. ${ }^{16}$ Gladstone agreed with the Government that an extension was necessary. He acknowledged that the state of affairs was not yet settled enough to warrant the removal of the suspension. Furthermore, Parliament was about to recess for six months, and in that time it would be impossible to re-assemble Parliament to pass another suspension if one were needed. 17

Gladstone also acknowledged that there was some justification in Irish discontent. He stated that the Government, by renewing the suspension of habeas corpus, "enhance and deepen their own obligation to recognize and appreciate the true condition of Ireland." 18 whatever grievances there were they could not be tied to the conduct of the Fenians. He noted that there were "those who look back to the history of Ireland [who] will feel that there are extenuating circumstances for political crimes in connection with the state of things that have existed for a long period."19 Those extenuating circumstances, however, did not apply to the Fenians. To Gladstone, if there was a series of acts that exhibited the "virulence and malignity of Fenianism" it was the attack on Canada. ${ }^{20}$ Canada, which had not done anything to the Irish or the Fenians, had been the victim of a "ruthless, and murderous act . . ."21

Gladstone was convinced that Fenianism was a cancer-a foreign cancer. He felt that in order to cure the 
patient, Ireland, it was necessary to first surgically remove the tumor. Then the patient could be helped by way of rehabilitation. By the end of 1866 Gladstone was beginning to realize that the government would have to consider addressing Irish grievances sometime soon. He was not, however, ready to commit either himself or the Liberal Party to a program of reform. 22

By early 1867 Gladstone was willing to consider some reform of Irish grievances. The Fenians had not disappeared. In fact, they had attempted several abortive risings in Kerry and around Dublin and Munster (February 12 to March 6, 1867). The Fenians had also attempted the raid on Chester Castle on the 14th of February. The Fenians in every instance had proven themselves totally incompetent. They had also proven themselves to be extremely durable. Despite the suspension of habeas corpus in Ireland, they had still been able to attempt a few risings in Ireland. More ominously, some of their activities now centered on England. Gladstone was moving, albeit slowly, toward the realization that something had to be done for Ireland. Yet he still proceeded cautiously. By the time of Gray's motion in 1867, he was willing, as an individual member, to support the formation of a committee to look into the condition of the Church of Ireland. He was not willing to commit the party to a program of Irish reform. As late as July of 1867, Gladstone still felt that all he could give was his 
personal support. Cardinal Cullen asked Gray to clarify Gladstone's position on the church question. Gladstone told Gray that he was "personally free to support any adjustment approved by Ireland." 23 Gladstone, by mid-1867, was much more willing to address the issue of Irish church reform, yet he refused to acknowledge that it was an issue to be considered by the Liberal Party. Gladstone still did not feel that immediate action needed to be taken to reform the church on the part of the Party. Only after extensive study could either the Liberal Party or the country be ready to accede to the demands of the Irish. 24

The event at Manchester proved to be of great significance. Not long after the incident he confided to John Bright, who recorded it in his diary, that the time had come to disestablish the Irish church: "An hour and a half with Mr. Gladstone this morning on future politics: on Ireland in particular. He is willing wholly to suppress State church in Ireland, but with a wish it had not been necessary." 25 In a conversation with General Grey, after it was obvious that he [Gladstone] was to be the next Prime Minister, he told Grey that "he had made up his mind . . that the Irish church must be dealt with, when reading in the railroad, the account of the Fenian prisoners at Manchester." 26

What was it about Manchester that so galvanized Gladstone? What was it about the events at Manchester that 
convinced Gladstone that the time to end the established Church of Ireland was at hand? Gladstone had stated in his speech in support of the first suspension of the Habeas Corpus Act (on February 17, 1866) that,

two generations ago a well spread rebellion in Ireland would have plunged whole provinces or extended districts in blood. In 1822, when the Habeas Corpus Act was suspended, there was a spirit of disaffection, powerful not in numbers only, but in other elements of stryength, and that was not of foreign introduction.

Gladstone also claimed in this same debate that the Irish, by their own "means and resources exclusively . . [ [could] effectually and quickly extinguish all the machinations of those disloyal and misguided men." 28 clearly the reaction to the events at Manchester had shown the Irish ready to give sympathy to the Fenian cause. The actions of Daunt, Cullen and The O'Donoghue clearly illustrated Ireland's discontent with Parliament's progress on the question of Irish reform. 29

once Gladstone had decided that the Irish church had to be disestablished, he wasted little time in acting on his conviction. At Southport he gave a speech before his constituents that outlined his views. He asked the audience if they would for one moment tolerate a Catholic church imposed upon them from without. He claimed that he wanted Ireland to be like scotland so that "instead of hearing in every corner of Europe the most painful commentaries upon the policy of England towards Ireland--we may be able to 
look our fellow Europeans of every nation in the face - . 30 Gladstone went on to repeat the vast majority of arguments that he had heard in parliament in favor of disestablishment. 31

In February 1868 Gladstone read a book by John Maguire, entitled The Irish in America. ${ }^{32}$ The book was written in 1867, and was based on Maguire's travels in the United States and Canada.

Maguire's book was an attempt to determine the opinion of Irish-Americans toward Great Britain. He wrote in the introduction that he was,
- - anxious to ascertain the real nature, that is the strength or the intensity of the sentiment which I had reason to believe was entertained by the Irish in the United States towards the British Government; as I considered, and I hold rightly, that the existence of a strong sentiment or feeling of hostility is a far more serious cause of danger, in case of future misunderstanding or complication than any organization, however, apparently extensive The book was also a call for Irish reform. Maguire hoped to promote Irish reform in Parliament in order to stop the steady deterioration of relations between Irish Catholics and the English. Maguire felt that any organization, no matter how small and disorganized, could grow as long as it could feed off of popular discontent:

Though an organisation may be ill-designed or even ridiculous, or, on account of the folly, or violence, or treachery, of those who are responsible for its management, may come to a speedy dissolution, if it has its origin in an earnest and enduring feeling, it is significant of danger--it represents 
more than is seen; and die down as it may 34 it is sure to spring up again in some new form.

Maguire was, in the main, referring to the Fenians. Maguire felt that the Fenians were not interested in reform--because reform would undermine the basis of their support:

The thorough-going Fenians--whether leaders or actors, or rank and file--would, if anything, prefer that the admitted causes of Irish discontent should not be removed; for they naturally argue--'If our hopes of regenerating Ireland be based upon revolution, it is better for our purpose that the various causes and sources be allowed to exist, and by their prolonged existence irritate and gall the public more and more, and thus keep the people in a condition most favorable to revolutionary teaching.'

Maguire compassionately called for reform while there was still time. He felt that as long as there were legitimate grievances in Ireland, that unhappy island would always be a problem for England--even if the Fenians disappeared:

- . though Fenian leaders may quarrel or betray, and Fenian organisations may wither or collapse there must be perpetual danger to the peace, the honour, if not the safety of England, from a power which it is impossible 3 to ignore, and madness to despise . .

The Fenians were a symptom of a greater illness. Thus, reform was not a surrender to Fenian demands. The Fenians were not directly concerned with the question of the church of Ireland. Church disestablishment, however, did serve the purpose of removing a grievance. Once that grievance had been removed, Maguire thought that Ireland would again be serene and comfortable in her relations with England. 
On March 16, 1868, Gladstone rose to give a speech upon Maguire's motion for a committee to look into the state of Ireland. He accused the government of failing to realize "in any degree at all approaching truth, the grave, and I would say solmn, fact that we have reached a crisis in the history of Ireland." 37 Gladstone's words, although true, seem to be too harsh on the Conservatives. After all, while his party was in power, he and the Liberals had done little to address Irish discontent. Certainly, E. R. Norman has touched upon part of the reason. Norman feels that Gladstone addressed the issue of disestablishment in 1868 in order to head off the government's intent to address the issue of education. Gladstone did not believe, by 1868 , that the government should fund Catholic education. The Catholics, on the other hand, had no desire to see the spread of secular schools. The Conservative government wanted to address the issue of Irish reform by giving the Catholics part of what they wanted--denominational schools paid for by the state. Gladstone hoped to head off this action by holding out a larger prize: church disestablishment. 38 This perhaps makes Gladstone look opportunistic. Gladstone, as A. Ramm has pointed out, was more than willing to use power to further his own ambition. Yet there is no doubt, however, that his ambition was tempered by a strong sense of duty and morality; and certainly he would have preferred that Ireland be reformed 
by his plans and ideas, not those of a minority government.

Yet, Norman's analysis does not completely answer why the idea of addressing Irish grievances was so important to both Gladstone and the Conservatives in 1868. In his speech, and in others, including his 1868 election pamphlet, A Chapter of Autobiography, he constantly addressed the problem of the Fenians. He asked why the Irish in Canada and Australia had not revelled at the first sign of Fenian activity in their countries:

Neither in Canada nor in Australia does the Irishman labour under the slightest difficulty with regard to the legal security he enjoys for the fruits of his industry and labour, nor is he confronted by the spirit or the remaining institutions of a hostile ascendancy.

The English, he continued, had seen the "loathsome disease of Fenianism overflow into England." 41 Gladstone further indicated that he had at long last recognized the pervasive nature of Irish discontent:

in the present state of Ireland, with its suspended liberties and its continuing evils assuming a subtler, but perhaps on that account, a more formidable shape, and viewing that state of things which has grown up in this country in no small degree under the influences of the changes proposed and promoted by Her Majesty's present administration, I recognized that the time has come when this question ought to be broached, and when it is broached it ought to be dealt with once for all.42

On March 20, 1868, he gave notice that he was going to present several motions to disestablish the Irish church. ${ }^{43}$ Gladstone came to the conclusion, after the incident at Manchester, that the time for disestablishment had arrived. 
What was to be gained by wooing the Irish away from the Fenians? A consistent theme through many of his speeches was the need to maintain the union between Ireland and Great Britain. In 1866, in a speech on the suspension of the Act of Habeas Corpus, Gladstone had claimed:

We do not propose this measure because we believe that it is through English influence and English regiments that the connection between the two countries to be maintained. My firm belief is that the influence of Great Britain in every Irish difficulty is not a domineering and tyranizing, but a softening and mitigating influence; and that were Ireland detached from her political connection with this country, and left to her own unaided agencies, it might be that the strife of parties would there burst forth in a form calculated to strike horror through the land...

He repeated this sentiment two years later when he said that delay in addressing Irish grievances "tends to compromise and cripple the strength of the empire." 45 In 1863 the Irish, while to some degree discontented, had not seemed overly so. The events after Manchester illustrated that a significant portion of Irish society was seriously discontented. They were, in fact, discontented enough to express sympathy for an organization that they had earlier condemned. Gladstone realized that the continued existence of outstanding grievances could possibly convince many Irish that the only way to redress those grievances would be to break the ties between Great Britain and Ireland. Gladstone, the cautious politician that he was, needed proof of that discontentment. Public sympathy for the 
Fenians provided the impetus that Gladstone needed to introduce motions for the disestablishment of the Irish church. 
Notes

1 Hardy, Diary 65 , note 4 .

2 Gladstone, Diaries, vol. 7, 28 April 1869, 61-62.

3 Quarterly Review Jan. and Apr. 1868: 269.

4 see pages 92-98.

5 See pages $61-80$.

6 see page 62 .

7 Hansards CLXXXI (1866): 25 .

8 Hansards CLXXXI (1866): 25.

9 Hansards CLXXXI (1866): 717-718.

10 Hansards CLXXXI (1866): 1040 .

11 Hansards CLXXXI (1866): 721 .

12 Hansards CLXXXI (1866): 686. Gladstone quoted Bright on page 710 .

13 Hansards CLXXXI (1866): 716-719.

14 Hansards CLXXXI (1866): 720 .

15 Hansards CLXXXI (1866): 722 .

16 This renewal was requested by the conservatives, who were now in power.

17 Hansards CLXXXIV (1866): 1944-1946.

18 Hansards CLXXXIV (1866): 1940.

19 Hansards CLXXXIV (1866): 1944.

20 Hansards CLXXXIV (1866): 1945.

21 Hansards CLXXXIV (1866): 1945.

22 Nor would he have been able to do so entirely on his own since Earl Russell was still the leader of the 
Liberal Party.

23 Norman, Catholic Church 332.

24 see page 69.

25 Bright, Diary, 30 Nov. 1867, 313.

26 George Buckle, ed., Letters of Queen Victoria, 2nd series, vol. 1 (New York: Longmans, Green \& Co., 1926) 562.

27 Hansards CLXXXI (1866): 723 .

28 Hansards CLXXXI (1866): 723 .

29 See pages 105-106.

30 Times 20 Dec. 1867.

31 see the Times 20 Dec. 1867.

32 Gladstone used portions of Maguire's book in his speeches in the 1868 election. Gladstone, Diaries, vol. 6, 570 , note 7 .

33 Maguire ix.

34 Maguire 590.

35 Maguire 610.

36 Maguire 624 .

37 William E. Gladstone, Speeches on Great Questions of the Day (London: J. C. Hotten, 1869) 104.

38 Norman, Catholic Church 240-280.

39 A. Ramma, "Gladstone as Politician, Gladstone, Politics, and Religion, ed. Peter Jagger (London: MacMillan, 1985) 105 .

40 Gladstone, Speeches 108.

41 Gladstone, Speeches 109. 
42 Gladstone, Speeches 137.

43 Hansards CXC (1868): 1974.

44 Hansards CLXXXI (1866): 716.

45 Gladstone, Speeches 106. 


\section{CONCLUSION}

\section{PACIFY IRELAND}

Gladstone, as we have seen, was a cautious and careful politician--to a degree. Before 1867 he was willing to consider disestablishment as a "future" question. In this sense he was not a politician motivated by a crisis. His preferred method of operation was to work the issue out slowly--as he attempted to do with parliamentary reform in 1865. Once the situation hit crisis proportions, however, that element in him that Magnus called "volcanic" erupted. 1 The results of such a political technique had profound effects. To the Irish it seemed as if the only way to get reform was through exhibitions of large scale discontent. O'Neill Daunt noted in his journal a letter from carvell williams: "He seems to think that this Fenian affair may accelerate the disendowment of the state Church by compelling statesmen to take measures calculated to remove or diminish the prevalent disaffection." 2 Nor was the timing of disestablishment lost upon the Fenians:

When William E. Gladstone in 1869 introduced the Bill to disestablish the Protestant Church in Ireland, he admitted in his speech that his new outlook on Irish affairs was due to the intensity of Fenianism. His remarks on that occasion proved a stronger argument in favor of physical force--and even Terrorism--on the part of Ireland to secure 3 justice and freedom than any Irishman ever made. 
Gladstone had succeeded in disestablishing the Irish church, yet, with advantage of hindsight, he also in a sense helped continue the awareness on the part of the Irish that only violence could convince the English to take note of Irish grievances.

How can we make sense of the Fenian contribution to Gladstone's decision to disestablish the Irish church in 1868? E. R. Norman has stated that Gladstone was convinced of the "urgency" to act by the Fenians. " In a sense he is correct, but the influence of the Fenians went beyond a sense of "urgency." Gladstone's words, now famous, upon hearing that he was to become Prime Minister were, "My mission is to pacify Ireland." Ireland, by late 1867, was in a chronic state of discontent. The fact that the Fenians were gaining support among the Irish disturbed the English. The fact that they were considered to be a foreign import by the English only added to the realization that, if grievances were allowed to fester, the Irish would cleave to any form of rebellion--no matter where it came from nor how ridiculous it might be. Disestablishment, in part, was intended to help smooth over the rising discontent in Ireland. Earl Spencer, who was appointed Viceroy of Ireland in 1868, commented in a letter to Lord $\mathrm{Clarendon}$ that "I am sure that the church Act has had a beneficial effect on the Priests; but their inveterate passion for politics keeps them still in excitement. . ." 5 
The Fenians played a significant role in Gladstone's timing on the Irish church question. Until the Fenians presented Gladstone with the spector of an Ireland riven from England, he had been content to allow the issue to proceed at a slow and steady pace. Gladstone moved quickly to redress Irish grievances once the Fenians, after the incident at Manchester, had shown that they could generate sympathy on the part of a large number of the Irish. The Fenians did more than convince Gladstone of the urgency of disestablishment. They convinced him that to delay any further would seriously jeopardize the existence of the union between the two nations. F. S. L. Lyons caught the essence of the significance of the Fenians to Irish history. While Fenian violence turned many against the Irish, - it could equally well prompt thoughtful men
to look beyond the violence to what had created the
violence and to wonder if the time had not come to
woo Ireland from the path of desperation by a
sustained attempt at constructive reform. That one
of those who now began to think this way was
Gladstone was not the least, if perhaps the most
unexpected of the legacies left by the Fenians to
posterity. 
Notes

1 Magnus 76 .

2 w. J. O'Neill Daunt, A Life Spent for Ireland

(1896; Dublin: Irish UP, 1927) 16 March 1867, 236.

3 John Devoy, Recollections of an Irish Rebel (New

York: C. P. Young, 1929) 250.

4 Norman, Catholic Church, 339.

5 Peter Gordon, ed., The Papers of the Fifth Earl

Spencer (Delapse Abbey, Northampton: Northamptonshire

Record Society, 1981) 26 October 1869, 79.

6 Lyons 127. 
SELECT BIBLIOGRAPHY

PRIMARY MATERIAL

\section{Annual Register}

Argyll, Eighth Duke of. Autobiography and Memoirs. 2 vols. 1906.

Blakiston, Noel, ed. The Roman Question. London: Chapman and Hall, 1962 .

Bright, John. The Diaries of John Bright. Ed. R. A. J. Walling. New York: William Morrow \& Co., 1931.

--- Speeches on Questions of Public Policy by the Right Honorable John Bright, M.P. Ed. James Rogers et al. London: MacMillan and Co., 1880 .

Buckle, George, ed. The Letters of Queen Victoria. 2nd series. New York: Longmans, Green \& Co., 1926.

Cavendish, Lady Frederick. The Diary of Lady Frederick Cavendish. Ed. J. Bailey. London: John Murray, 1927.

Daunt, w. J. O'Neill. Ireland and Her Agitators. Dublin: P. C. D. Warren, n.d.

-- A Iife Spent for Ireland. Dublin: Irish UP, 1927. (first published in London: T. Fisher Union, 1896).

Devoy, John. Recollections of an Irish Rebel. New York: C. P. Young, 1929 .

Foreign Relations of the United States. New York: Kraus Reprint Corp., 1965.

Gladstone, William E. "A Chapter of Autobiography". Gleanings of Past Years. Vol. 7. London: John Murray, 1879, 97-151.

--- Correspondence on Church and Religion of W. E. Gladstone. Ed. D. C. Lathbury. London: John Murray, 1910. 
--- The Gladstone Diaries. Ed. H. C. G. Matthew. Oxford: Clarendon Press, 1982.

--- Speeches of the Right Honourable William Ewart Gladstone, M.P., in South-West Lancashire, October 1868. Liverpool: E. Smith \& Co., 1868 .

--- Speeches on Great Questions of the Day. 2nd ed. London: J. C. Hotten, 1869 .

--. W. E. Gladstone (The Prime Ministers' Papers Series). Ed. John Brooke and Mary Sorenson. London: Her Majesty's Stationary office, 1978.

Guedalla, P., ed. Gladstone and Palmerston. New York: Harper and Brothers, 1928 .

--- The Queen and Mr. Gladstone. 2 vol. Garden City: Doubleday, Doran \& Co., 1934.

Hansards Parliamentary Debates, third series (1830-1891).

Hardy, Gathorne. Diary of Gathorne Hardy, Later Lord Cranbrook, 1866-1892: Political Selections. Ed. Nancy Johnson. Oxford: Oxford UP, 1981.

Illustrated London News.

Maguire, John F. The Irish in America. New York: Arno Press, 1969.

Quarterly Review.

Ramm, Agatha, ed. The Political Correspondence of Mr. Gladstone and Lord Granville 1868-1876. 2 vol. Oxford: Oxford UP, 1952.

Russell, Lord John. The Later Correspondence of Lord John Russe11. Ed. G. P. Gooch. London: Longmans, Green and Co., 1925.

Russell, John Earl. Recollections and Suggestions. Boston: Roberts Brothers, 1875 .

Smith, Goldwin. Reminiscences. New York: MacMillan Co., 1910 .

Spencer, Fifth Earl. The Red Earl. The Papers of the Fifth Earl Spencer. Ed. Peter Gordon. Delapse Abbey: Northamptonshire Record Society, 1981. 
Stanley, Lord Edward Henry. Disraeli, Derby and the Conservative Party. Journals and Memoirs of Edward Henry, Lord Stanley. Ed. John Vincent. New York: Barnes \& Noble, 1978.

The Times (London).

West, Sir Algernon. Recollections. New York: Harper and Publishers, 1900 .

\section{SECONDARY MATERIAL}

Beales, Derek. "Gladstone and His First Ministry." Historical Journal 26 (1983): 987-998.

Beckett, James $C$. The Anglo-Irish Tradition. Ithaca: Cornell UP, 1976.

--- The Making of Modern Ireland, 1603-1923. New York: Knopf, 1966, 1969.

--- A Short History of Ireland. London: Hutchinson, 1966 .

Birrell, Francis. Gladstone. New York: MacMillan, 1933.

Blake, Robert. Disraeli. New York: St. Martin's Press, 1967.

Bottigheimer, Karl S. Ireland and the Irish. New York: Columbia UP, 1982 .

Bowen, Desmond. Paul Cardinal Cullen and the Shaping of Modern Irish Catholicism. Dublin: Gill and MacMillan, 1983.

Boyce, David G. Nationalism in Ireland. Baltimore: Johns Hopkins UP, 1982 .

Checkland, S. G. The Gladstones. A Family Biography 1764-1851. Cambridge: Cambridge UP, 1971.

Comerford, R. V. The Fenians in Context. Dublin: Wolfhound Press, 1985.

Drew, Mary. Acton, Gladstone and Others. Freeport: Books for Libraries, 1968 . 
Edinger, George A., and E. J. C. Neep. The Grand Old Man; a Gladstone Spectrum. London: Meuthen, 1936.

Eversley, George. Gladstone and Ireland. The Irish Policy of Parliament From 1850-1894. London: Meuthen, 1912 .

Eyck, Erich. Gladstone. London: G. Allen \& Unwin, 1938.

Feuchtwanger, E. J. Democracy and Empire. Britain 1865-

1914. London: Edward Arnold, 1985.

--. Gladstone. New York: St. Martin's Press, 1975.

Gathorne-Hardy, Alfred Erskine. Gathorne Hardy, First Earl of Cranbrook. New York: Longmans, 1910 .

Gladstone, Herbert. After Thirty Years. London: MacMillan, 1928 .

Hamer, D. A. Liberal Politics in the Age of Gladstone and Rosebery. Oxford: Clarendon Press, 1972 .

Hammond, J. L., and M. R. D. Foot. Gladstone and Liberalism. London: English Universities Press, 1966 .

Hammond, J. L. Gladstone and the Irish Nation. 2nd ed. Hamden: Archon Books, 1964 .

Hanham, H. J. Elections and Party Management. New York: Longmans, 1959 .

Harmon, Maurice, ed. Fenians and Fenianism. Seattle: University of washington Press, 1970 .

Hoppen, K. Theodore. Elections, Politics, and Society in Ireland 1832-1885. Oxford: Clarendon Press, 1984.

---. "The Franchise and Electoral Politics in England and Ireland 1832-1885." History 70 (1985): 202-217.

Jagger, Peter J., ed. Gladstone, Politics, and Religion. London: MacMillan, 1985.

Jenkins, T. A. "Gladstone, the Whigs, and the Leadership of the Liberal Party." Historical Journal 27 (1984): $337-360$.

Kinzer, Bruce L. The Gladstonian Turn of Mind. Toronto: University of Toronto Press, 1985. 
Larkin, Emmet. "The Devotional Revolution in Ireland, 1850-1875." American Historical Review LXXVII $(1872)=625-652$.

Lyons, F. S. L. Ireland Since the Famine. London: Fontana, 1973.

MacSuibhne, Peadar. Paul Cullen and His Contemporaries. Naas, Leinster Leader Ltd., 1961.

Magnus, Philip. Gladstone: A Biography. New York: E. P. Dutton, $196 \overline{4}$.

Mansergh, Nicholas. The Irish Question, 1840-1921.

Toronto: University of Toronto Press, 1965.

McDowell, R. B. The Irish Administration. Westport, Connecticut, 1964, 1976 .

Monypenny, William, and George E. Buckle. The Life of Benjamin Disraeli. New York: MacMillan, 1916.

Moody, T. W., et al. A New History of Ireland. Oxford: Oxford UP, 1976.

Moody, T. W., and Leon O'Broin. "The I.R.B. Supreme Council, 1868-78." Irish Historical Studies XIX, no. $75(1975): 286-3 \overline{32}$.

Moody, T. W., and F. X. Martin, ed. The Course of Irish History. Cork : Mercier Press, 1967.

Morley, John. The Life of William Ewart Gladstone. New York: MacMillan Co., 1921 (1903).

Newsinger, John. "Old Chartists, Fenians, and New Socialists." Eire-Ireland 17 (1982): 19-45.

Norman, E. R. The Catholic Church and Ireland in the Age of Rebellion 1859-1873. Ithaca: Cornell UP, 1965.

--- A History of Modern Ireland. London: Allen \& Urwin, 1971.

O'Broin, Leon. Revolutionary Underground. Dublin: Gill and MacMillan, 1976.

O'Farrell, Patrick. England and Ireland Since 1800. Oxford: Oxford UP, 1975.

--- Ireland's English Question. New York: Schocken Books, 1971. 
Prest, John. Lord John Russell. Columbia: University of South Carolina Press, 1972.

Quinlivan, Patrick, and Paul Rose. The Fenians in England 1865-1872. New York: Riverrun Press, 1982.

Ramm, Agatha. "Gladstone's Religion." Historical Journal $28(1985): 327-340$.

Read, Donald. England, 1868-1914: The Age of Urban Democracy. New York: Longman, 1979.

Richter, Donald C. Riotous Victorians. Athens: Ohio UP, 1981 .

Ryan, Desmond: The Fenian Chief. A Biography of James Stephens. Coral Gables: University of Miami Press, 1967.

Shannon, Richard. Gladstone. Chapel Hill: University of North Carolina Press, 1984 .

Smith, Goldwin. Irish History and Irish Character. oxford \& London: J. H. and J. Parker, 1862.

---. My Memory of Gladstone. London: T. F. Unwin, 1904.

Stansky, Peter. Gladstone. A Progress in Politics. New York: W. W. Norton, 1979 .

Steele, E. D. "Gladstone and Ireland." Irish Historical Studies 17, no. 65: 58-88.

Thomson, David. England in the Nineteenth Century. New York: Penguin Books, 1950, 1978 .

Townshend, C. "Modernization and Nationalism: Perspectives in Recent Irish History." History LXVI (1981): 231-243.

Townshend, Charles. Political Violence in Ireland. Oxford: Clarendon Press, 1983.

Trevelyan, G. M. The Life of John Bright. Boston: Houghton Mifflin Co., 1913.

Vincent, John. The Formation of the British Liberal Party. New York: Scribner, 1966.

Walker, Mabel G. The Fenian Movement. Colorado Springs: R. Myles, 1969 . 
Whyte, J. H. "Bishop Moriarty on Disestablishment and the Union, 1868." Irish Historical Studies X (1956): 193-199.

Whyte, John. "The Influence of the Catholic Clergy on Elections in Nineteenth-Century Ireland." English Historical Review LXXV (1960): 239-259.

Williams, W. E. The Rise of Gladstone to the Leadership of the Liberal Party, 1859-1868. New York: Octagon Books, 1934, 1973.

Woodward, Ernest L. The Age of Reform, 1815-1870. Oxford: Clarendon Press, 1938, 1962 . 